\title{
CIVIL AFFAIRS AND MILITARY GOVERNMENT OPERATIONS IN POST-FASCIST ITALY
}

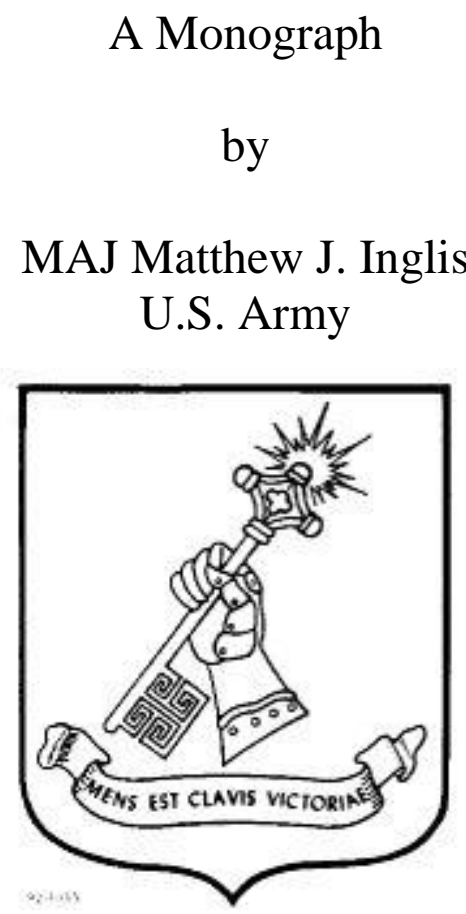

School of Advanced Military Studies

United States Army Command and General Staff College

Fort Leavenworth, Kansas

2014-01

Approved for public release; distribution is unlimited. 


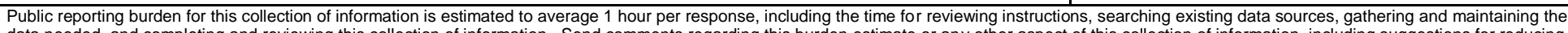

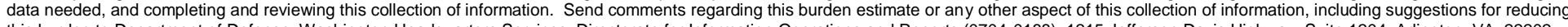

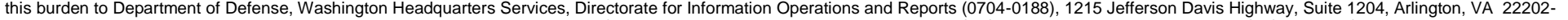

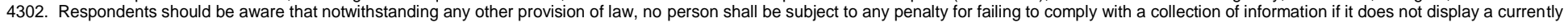
valid OMB control number. PLEASE DO NOT RETURN YOUR FORM TO THE ABOVE ADDRESS.

\begin{tabular}{l|l|l} 
1. REPORT DATE (DD-MM- $Y Y Y Y)$ & 2. REPORT TYPE & 3. DATES COVERED (FrOm - To)
\end{tabular}

22 MAY $2014 \quad$ Master's Thesis

4. TITLE AND SUBTITLE

Civil Affairs and Military Government Operations in Post-Fascist Italy

JUN 2013-MAY 2014

5a. CONTRACT NUMBER

5b. GRANT NUMBER

5c. PROGRAM ELEMENT NUMBER

6. AUTHOR(S)

Major Matthew J. Inglis, U.S. Army

5d. PROJECT NUMBER

7. PERFORMING ORGANIZATION NAME(S) AND ADDRESS(ES)

School of Advanced Military Studies

5e. TASK NUMBER

5f. WORK UNIT NUMBER

250 Gibbon Ave.

Ft. Leavenworth, KS 66027

9. SPONSORING / MONITORING AGENCY NAME(S) AND ADDRESS(ES)

U.S. Army Command and General Staff College

ATTN: ATZL-SWD-GD

Fort Leavenworth, KS 66027-2301

8. PERFORMING ORGANIZATION REPORT NUMBER

10. SPONSOR/MONITOR'S ACRONYM(S)

\section{DISTRIBUTION / AVAILABILITY STATEMENT}

Approved for Public Release; Distribution is Unlimited

\section{SUPPLEMENTARY NOTES}

\section{ABSTRACT}

This monograph examines how the Allied governments planned and executed civil affairs and military government operations in Italy during World War II. Many have explored and researched the outcome following the defeat of Germany and Japan, but the circumstances with Italy are distinctive. Specifically, the application of civil affairs and military governance in Italy is an area that appears to be underexplored despite its relevance in current military operations. Reviewing the Allied preparations and assessing the challenges faced in this area allows one to derive the influence of an evolving political situation on military operations. This monograph argues that the Allies were largely unprepared for the enormity of the civil affairs mission in Italy. While the Allied governments were successful in establishing the basic education and organization for the civil affairs mission, the political pressures and conflicting strategic guidance hindered military efficiency towards the effort. The Allies conducted military governance simultaneously with military operations against German, the Allies assumed the dual role of liberator and occupier. This dual role is most recently seen in the military operations in Iraq and Afghanistan, which makes this historical case study of even higher relevancy.

15. SUBJECT TERMS

Civil Affairs and Military Government, Allied Military Government, Italian Theater

\begin{tabular}{|c|c|c|c|c|l|}
\hline \multicolumn{2}{|l|}{ 16. SECURITY CLASSIFICATION OF: } & $\begin{array}{l}\text { 17. LIMITATION } \\
\text { OF ABSTRACT }\end{array}$ & $\begin{array}{l}\text { 18. NUMBER } \\
\text { OF PAGES }\end{array}$ & 19a. NAME OF RESPONSIBLE PERSON \\
\cline { 1 - 2 } a. REPORT & b. ABSTRACT & c. THIS PAGE & & & \\
(U) & (U) & (U) & (U) & 50 & \\
\hline
\end{tabular}




\title{
MONOGRAPH APPROVAL PAGE
}

Name of Candidate: MAJ Matthew J. Inglis

Monograph Title: Civil Affairs and Military Government Operations in Post-Fascist Italy

Approved by:

Robert T. Davis II, Ph.D.

, Monograph Director

\author{
Robert T. Davis III, Ph.D.
}

.

(3)

, Monograph Director




\begin{abstract}
CIVIL AFFAIRS AND MILITARY GOVERNMENT OPERATIONS IN POST-FASCIST ITALY, by MAJ Matthew J. Inglis, 87 pages.

This monograph examines how the Allied governments planned and executed civil affairs and military government operations in Italy during World War II. Many have explored and researched the outcome following the defeat of Germany and Japan, but the circumstances with Italy are distinctive. Specifically, the application of civil affairs and military governance in Italy is an area that appears to be underexplored despite its relevance in current military operations. Reviewing the Allied preparations and assessing the challenges faced in this area allows one to derive the influence of an evolving political situation on military operations. This monograph argues that the Allies were largely unprepared for the enormity of the civil affairs mission in Italy. While the Allied governments were successful in establishing the basic education and organization for the civil affairs mission, the political pressures and conflicting strategic guidance hindered military efficiency towards the effort. The Allies conducted military governance simultaneously with military operations against German, the Allies assumed the dual role of liberator and occupier. This dual role is most recently seen in the military operations in Iraq and Afghanistan, which makes this historical case study of even higher relevancy.
\end{abstract}




\section{ACKNOWLEDGMENTS}

I wanted to take a quick minute to acknowledge and thank a few people who supported my efforts during this entire monograph process. First I would like to thank my wife, Amber, for ignoring the piles of books for research, and supporting my absence during the long hours. I would also like to thank COL Uwe Jansohn, my Seminar Leader for his continued encouragement to meet all the milestones during this process and produce a project that I was truly proud of. Lastly, I would like to acknowledge Dr. Robert Davis, whose knowledge on the subject matter and lists of new references, continued to guide me through the research and synthesis process. His approach to the development of this monograph and my own development as a professional was truly appreciated. Thanks to all. 


\section{TABLE OF CONTENTS}

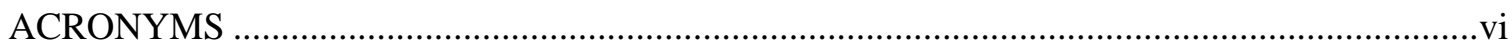

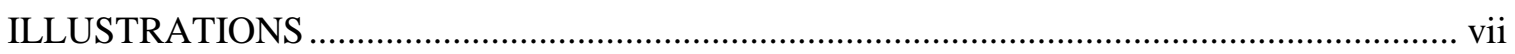

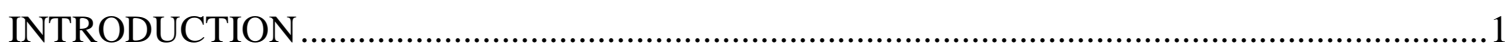

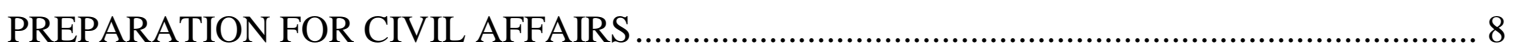

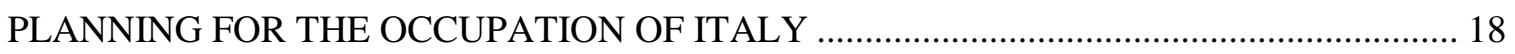

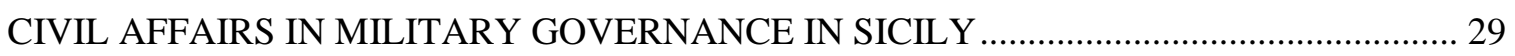

POLITICAL UPHEAVAL WITHIN THE ITALIAN GOVERNMENT …................................ 39

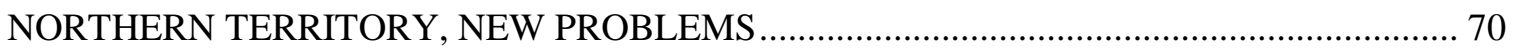

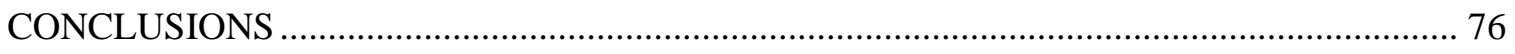

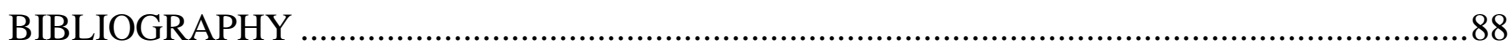




\section{ACRONYMS}

$\mathrm{AC}$

Allied Commission

ACC/AMG Allied Control Commission/Allied Military Government

AFHQ Allied Force Headquarters

AMG Allied Military Government

AMGOT Allied Military Government of Occupied Territory

CAO Civil Affairs Officer

CCS Combined Chiefs of Staff

CinC Commander in Chief

CNL Committee of National Liberation

MGS Military Government Section

WWI World War I

WWII World War II 


\section{ILLUSTRATIONS}

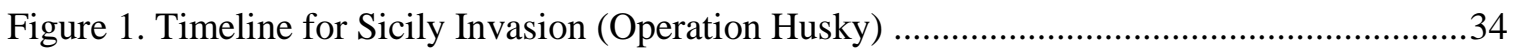

Figure 2. Allied Control Commission Regional Organizations as of 1 April 1944 .......................53

Figure 3. Administrative Boundaries for AMG as of October 1944 ...........................................61

Figure 4. Timeline for Transition of Territory to the Italian Government ................................... 71

Figure 5. Zones for Military Occupation in Germany ............................................................ 84 


\section{INTRODUCTION}

This is the first United States operation involving the invasion and occupation of enemy territory. It is the first British operation involving the invasion and occupation of enemy territory other than colonial. It is as well the first joint operation against enemy territory. It will inevitably establish precedents far-reaching in scope and importance and will set the pattern for later operations in Europe. Policies now adopted will affect future operations throughout the war. We must therefore reconcile American and British policy toward Italy in order so that there may be a joint and single attitude with respect to the civil and military authority and the civil population of the territory occupied.

- Letter from General Eisenhower to War Department in Coles and Weinberg, Civil Affairs: Soldiers Become Governors ${ }^{1}$

Allied civil affairs and military governance in Italy during World War II (WWII) is an important though understudied example of the challenges of transforming other societies under combat conditions. It is important to appreciate the fundamental difference between the Allied Forces' understanding of their role in civil affairs going into North Africa and later into Italy. Firmly established in the minds of political leaders and military planners, was the definitive distinction between liberation of a country and the occupation of an enemy's territory. Italy was the first test of the execution of Civil Affairs in Military Governance for the Allied Forces in the truest sense of this operating concept. Liberation called for civil affairs operations and the reinstitution of the previous governance with existing administrative centers and regulations. The occupation of an enemy country, however, called for the complete overhaul of governance often with the redesign of laws, systems, and leadership. The Allied Military Government's (AMG) challenge in Italy was how to simultaneously liberate and occupy the region while retaining the capability to grow combat power for a separate theater. Driven to remove the Fascist system based on Allied policy, Civil Affairs Officers (CAO) struggled with unique circumstances, resource shortages and an ever-changing political landscape within Italy, while stabilizing the environment for ongoing military operations.

\footnotetext{
${ }^{1}$ Harry Coles and Albert Weinberg, United States Army in World War II Special Studies: Civil Affairs: Soldiers Become Governors (Washington, DC: US Army Center of Military History, 2004), 160.
} 
This monograph explores the circumstances leading to and through initial military government operations in Sicily and the Italian mainland. It explores why the Allied forces were largely unprepared for civil affairs and military government operations in Italy following the initial successes of Operation Husky. Despite the test run in North Africa the previous winter, the disparity between the Vichy French and the challenges with the Italians were too difficult to reconcile for military planners and CAOs responsible for large occupied Italian territories. Italy was the first Axis belligerent whose national territory came under the Allied occupation. Political motivations and limitations placed upon Allied military leaders meant the restoration of an acceptable Italian Government was significantly challenging. In North Africa, the Vichy French quickly assumed a large portion of administration responsibilities for civil services. However, the Fascist bureaucracy in Italy required complete modification at nearly all levels and was mired by political instability. The nature of the occupation in Italy created an unwieldy organization of divided regions and separate headquarters that circumscribed the ease of Allied civil affairs operations. Additionally, the political interests of the United States and Great Britain, and later Russia, towards operations in greater Europe shaped the effort and resources devoted to the occupation of Italy. In conquered mainland Italy especially, the risk of failure in political and social objectives for establishing a non-fascist Italian administrative system was directly tied to future military interests for the rest of the European continent.

The importance of civil affairs operations was established in both British and American circles leading up to World War II. Even though conditioned by war, civil affairs concerns are chiefly social problems that involve human nature rather than technological or tactical factors. Despite the social aspect, these operations were very labor intensive and drained the resources of the Mediterranean force, which the Allied Commander in Chief (CinC), Lieutenant General Dwight Eisenhower, hoped to minimize. The resources and efforts applied to the establishment of AMG directly constrained military equipment, personnel and focus for the Seventh, Eighth 
Armies, and later the Fifth Army. If a quick transition to Italian control was viable, then personnel and resources could be used to defeat the German forces in northern Italy and spare resources for a cross-channel attack. The balancing of these multiple demands greatly changed the face of Civil Affairs in Military Government operations at the local and national levels, often to the detriment of the Italian people and military efficiency.

The primary focus of this monograph is to provide a detailed study of the planning and execution of civil affairs and military government operations in occupied Italy. Developing a narrative based on the synthesis of primary and secondary sources of the Allied civil affairs and military government in Italy, this monograph illustrates the challenges faced by the leaders and soldiers involved. Additionally, this narrative examines how the guidance and political pressures placed upon the Allied CinC during the simultaneous execution of major combat operations and the establishment of administrative government hindered his forces' freedom of action in the theater. The political climate within Italy was rapidly shifting and unforeseen events altered the concept of military government operations and its execution. The improper transition of civil affairs operations to civilian control placed a significant strain on the Allied armies' resources during the period of combat hostilities. The complication and political tension placed upon civil affairs and military government operations leading up to the surrender of Italy, declaration as a co-belligerent, and eventual liberation are discussed.

Observers of the Allied actions in Italy have provided differing narratives regarding civil affairs and military government. Differentiated by the focus of the research, each observer recognized the detailed complexity of the environment, both militarily and politically, in which CAOs and staffs operated. The starting point for any inquiry into civil affairs in WWII are the official histories produced by the British and United States governments. The early historical narrative of Robert W. Komer's Civil Affairs and Military Government in the Mediterranean 
Theater produces the factual groundwork regarding the Allied actions in Italy. ${ }^{2}$ The Review of Allied Military Government and of the Allied Commission in Italy by the Public Relations Branch of the Allied Commission illustrated the trial and error method seen in AMG operations. ${ }^{3}$ This insightful publication provides an overview of AMG operations, often providing the personal accounts from civil affairs officers during the campaign. The great portion of the analysis of these early official histories is seen the Special Studies series. The Special Studies conducted by Center of Military History that featured the Mediterranean theater was titled Civil Affairs: Soldiers Become Governors by Henry Coles and Albert Weinberg. ${ }^{4}$ This assembly of primary documentary material and analysis creates the tapestry of civil affairs and military government operations through North Africa and into Italy. It illustrates the problems of civil affairs, their character, approaches to their solution, and their impact on the people who dealt with them. ${ }^{5}$ Additionally, this source highlights the conflicting national and personal interests of the actors involved, and the squaring of political idealism with military necessity in a combat environment. Supplemented by other historical sources, such as The Mediterranean Theater of Operations: Sicily and the Surrender of Italy, by Albert Garland and Howard Smyth, the historical narrative at the tactical level illustrates the growing pains with the Allies first true occupation of a belligerent. ${ }^{6}$ The narrative in all the historical sources focuses on the major problems encountered during the Allies' first attempt at Civil Affairs in Military Government and the concept of a joint

\footnotetext{
${ }^{2}$ Robert Komer, Civil Affairs and Military Government in the Mediterranean Theater (Washington, DC: Department of the Army, 1950).

${ }^{3} \mathrm{US}$ Army, Review of Allied Military Government and of the Allied Commission in Italy, Public Relations Branch, Allied Commission, 1945.

${ }^{4}$ Coles and Weinberg.

${ }^{5}$ Ibid., Forward.

${ }^{6}$ Albert Garland and Howard Smyth, The Mediterranean Theater of Operations: Sicily and the Surrender of Italy (Washington, DC: US Army Center of Military History, 2004).
} 
military government system of an occupied territory. Thoroughly testing the planning, organization and execution of civil affairs and military government, the Italian campaign provided a multitude of unforeseen events, political influence, and upheaval.

The second group of narratives highlights competing interests and intentions of the United States and United Kingdom. The Italian campaign provided the truest execution of joint operations between the United States and United Kingdom ever attempted, and the execution of Civil Affairs in Military Government was no exception. The narrative of institutional and operational differences between British and American Forces is highlighted in works such as William Daugherty and Marshall Andrews' A Review of US Historical Experience with Civil Affairs, 1776-1954 and F.S.V. Donnison's Civil Affairs and Military Government Central Organization and Planning. ${ }^{7}$ The establishment of AMG as a separate military organization consisting of mainly American and British civil affairs personnel under GEN Eisenhower's command allowed him to control the conquered territory of Italy. Officers and men with civil affairs training, received at their nation's civilian and military training centers, created the working dynamic between the two parties. In Thijs Zaalberg's Soldiers and Civil Power: Supporting or Substituting Civil Authorities in Modern Peace Operations illustrates how joint CAOs conducted operations. Zaalberg's narrative expounds how CAOs helped establish public order, managed the flow of refugees, prevented diseases, and exploited the host nation's logistical and infrastructural resources in support of the greater Allied effort to reestablish peace in Europe. ${ }^{8}$ Lastly, Hajo Holborn's American Military Government, Its Organization and Policies,

${ }^{7}$ William Daugherty and Marshall Andrews, A Review of Historical Experience with Civil Affairs, 1776-1954 (Baltimore, MD: Operations Research Office, John Hopkins University, 1961), F.S.V. Donnison, Civil Affairs and Military Government Central Organization and Planning (London: Her Majesty's Stationery Office, 1966).

${ }^{8}$ Thijs Brocades Zaalberg, Soldiers and Civil Power: Supporting or Substituting Civil Authorities in Modern Peace Operations (Amsterdam: Amsterdam University Press, 2006), 12. 
discusses in detail the preparation and relations between civil affairs and occupation of Italy and the carryover of the lessons learned to other theaters in Europe. ${ }^{9}$

The political narrative is by far most renowned and exemplifies the competing strategic players involved in the Allied campaign against the Axis Powers. This narrative helps define the character driven perspectives of Prime Minister Winston Churchill and President Franklin Roosevelt specifically, and how they perceived the execution of operations in Italy. Each leader influenced the rhetoric, proclamations, and guidance for the military force to best govern a defeated Italy. Sources such as Gaddis Smith's American Diplomacy during the Second War, 1941-1945, Mark Stoler's Allies and Adversaries, and C.R.S. Harris' Allied Military Administration of Italy, 1943-1945 all provide the political aspect towards military governance. ${ }^{10}$ Smith and Stoler share the American perspective towards diplomacy, while Harris provides the counterpoint with a successful inclusion of the British perspective. In Keith Sainsbury’s Churchill and Roosevelt at War, the grand strategy of the Allied campaigns is investigated. Sainsbury stressed the growing sense of unease between the Western and Soviet partners towards the future of Italy. ${ }^{11}$ The competing interests and personalities between the Allied military leaders and planners is also illustrated in Stoler's Allies and Adversaries. ${ }^{12}$ The multitude of conferences between the United States, United Kingdom, and Soviet Union developed the political situation created by the Italian surrender and co-belligerency. The outcome of the Casablanca, Quebec and

\footnotetext{
${ }^{9}$ Hajo Holborn, American Military Government: Its Organization and Policies (Washington, DC: Infantry Journal Press, 1947).

${ }^{10}$ Gaddis Smith, American Diplomacy during the Second World War, 1941-1945 (New York: John Wiley, 1965), Charles R.S. Harris, History of the Second World War, United Kingdom Military Series: Allied Military Administration of Italy (London: Her Majesty’s Stationery Office, 1957).

${ }^{11}$ Keith Sainsbury, Churchill and Roosevelt at War: The War they Fought and the Peace they Hoped to Make (New York: New York University Press, 1994).

${ }^{12}$ Mark Stoler, Allies and Adversaries: The Joint Chiefs of Staff, The Grand Alliance, and U.S. Strategy in World War II (Chapel Hill, NC: The University of North Carolina Press, 2000).
} 
Moscow conferences all directly apply to how Allied Forces executed operations of military governance in Italy.

One differing narrative is found in David Ellwood's Italy 1943-1945, which provides a more scathing Italian perspective on the impact of the Allied occupiers. ${ }^{13}$ It is the most critical review of military government operations in Italy based on the lasting repercussions of military governance on the Italian society during the war and for years after. Ellwood deftly reminds the reader of the conditions the soldiers faced and the removal of the local people from the power struggles at the political level. His focus is less on the high policy of the Allied occupation than the lasting implications for the Italian people.

There is also a doctrinal narrative derived from the military resources published at the time. For instance, Field Manual 27-5, The United States Army and Navy Manual for Civil Affairs Military Government, published in 1940 and revised in 1943 provided the basis for the understanding of the CAO mission. Additionally, the Soldier's Guide to Sicily, provides the framework from within which the individual Soldier could operate. Developed as a hip pocket guide, the handbook provides the necessary Dos and Do Nots for the military occupation. The various reports, telegraph messages, and assessments of primary players within Army Force Headquarters, the Military Government Section (MGS), and Allied Military Organization all reinforce the current understanding of the evolving situation in Italy. These reports support the conclusions of previous narratives while creating the timeline of events. Additionally, the multitude of sources for each of the artifacts dealing with the proclamations, public statements, official surrender and armistice agreements support the basic narrative.

\footnotetext{
${ }^{13}$ David Ellwood, Italy 1943-1945 (New York: Homes and Meier Publishers, 1985).
} 


\section{PREPARATION FOR CIVIL AFFAIRS}

The U.S. Army had a long, if episodic, experience with military governance and civil affairs prior to World War II. Leaders like General Scott in Mexico, and others through their experience generated a military consensus of the importance of civil affairs to a war effort. With considerable foresight, the U.S. War Department understood the challenges of the pending conflict and many learned the costly effects of unpreparedness following World War I. COL Hunt was the lead in the American Military Government in Germany in 1919, and brought back many lessons summarized in his official report. As noted by COL Irwin Hunt's report, the United States was largely unprepared for the occupation of Germany and establishment of civil governance. ${ }^{14}$ At nearly all levels, leaders only had the faintest conception of the German governmental system and were more inclined to the enforcement of Versailles Treaty than nation building. Additionally, the circumstances with 1919 Germany differed drastically from what unfolded in Italy during World War II. The signing of the Armistice on November 11 ended the war and combat operations. In Italy, combat operations continued for almost two years after the signing of the Italian Armistice. The World War I (WWI) Armistice only provided for Allied occupation up to the west bank of the Rhine, which took place under the provisions of the Armistice, not a formal surrender. ${ }^{15}$ Separated by their zonal boundaries, neither American, British, nor French forces established governance, and kept in line with General Foch's proclamation for limited occupation only. Civil Affairs in WWI did not assume legislative, executive, or judicial authority over the occupied territory. ${ }^{16}$ The Allies, especially from a British perspective, never intended to

\footnotetext{
${ }^{14}$ Coles and Weinberg, 6.

${ }^{15}$ Donnison, 17.

${ }^{16}$ Ibid.
} 
occupy and govern Germany, but only did so to ensure compliance with the terms of armistice. ${ }^{17}$ American and British CAOs sought to: (1) ensure that Germany paid reparations; (2) protect France from renewed aggression; and (3) demonstrate America's commitment to Europe. Despite not engaging formal planning and still having a limited number of trained soldiers to execute these missions, Allied civil affairs/military government activities restored order and maintained stability in occupied Germany. ${ }^{18}$

Despite the inherent need for a doctrinal basis, by 1939, the lessons from previous conflicts were inherently implicit within the military, guiding the commander with written and unwritten rules of warfare, such as Lieber's Code and the Hague Conventions of 1899 and 1907. ${ }^{19}$ Lieber's Code, also known as General Order No. 100, established by President Lincoln in 1863, better codifies the rules of war and in the area of civil affairs, truly applies the guidelines for military occupation and treatment of civilians. ${ }^{20}$ The Hague Conventions outlined the essence of Lieber's Code, but on an international stage, created a multi-national standard for the conventional Laws of War. ${ }^{21}$ Using the Hague conventions at its core, the United Kingdom took steps to formalize civil affairs and military governance training, following its experiences in the Italian colonies on the African continent. The British War Office inaugurated politico-military

\footnotetext{
${ }^{17}$ Donnison, 17.

${ }^{18}$ Kathleen Hicks and Christine Wormuth, The Future of U.S. Civil Affairs Forces, A Report of the CSIS International Security Program, February 2009, Center for Strategic and International Studies. http://csis.org/files/publication/130409_Hicks_FutureCivilAffairs_Web.pdf (accessed 20 February 2014), 3.

${ }^{19}$ Daugherty and Andrews, 194.

${ }^{20}$ The Avalon Project, "General Orders No. 100: The Lieber Code," Lillian Goldman Law Library, Yale Law School, http://avalon.law.yale.edu/19th_century/lieber.asp (accessed 23 March 2014). This was originally issued by the Adjutant General Office in 1863.

${ }^{21}$ International Committee of the Red Cross, Regulations concerning the Laws and Customs of War on Land. The Hague, 29 July 1899, http://www.icrc.org/ihl/INTRO/150?OpenDocument (accessed 13 December 2013).
} 
courses at St. Johns College, Cambridge, to train officers in post-war reconstruction and other missions incident to military operations in foreign countries. ${ }^{22}$ Two American officers, MAJ Henry Cummings, the United States Military Attaché in London, and LT Charles Thomson, an Infantry officer, became the first two United States military officers to undergo formal Civil Affairs training, attending the third round of politico-military training in England. ${ }^{23}$ In light of COL Hunt's report, many within the U.S. War Department sought to coopt the British model. Although the instruction neglected the areas of organization, supply, or actions within a combat zone, the two officers submitted a formal recommendation that the United States Army develop a similar course, laying the groundwork for the United States' own educational program. The politico-military courses dealt with history, geography, economics, and politics, aimed at giving students background knowledge rather than specific instruction on military government. ${ }^{24}$ However, the British disbanded the politico-military courses in the winter of 1941, due to necessity for the war effort but later reestablished it using the American model of Charlottesville in early $1943 .{ }^{25}$ Using the historical precedence of civil affairs, the U.S. War Department understood the need for a more defined and established system for military governance, and directed the Provost Marshal General with the "responsibility of training officers for future details in connection with military government and liaison."26

\footnotetext{
${ }^{22}$ Civil-Military Cooperation Centre of Excellence, CIMIC Messenger 5, no. 1 (March 2013): 5, http://www.cimic-coe.org/download/newsletter/CIMIC-Messenger-2013-01-final.pdf (accessed 9 January 2014).

${ }^{23}$ Civil Affairs Association, Origins of Civil Affairs, http://www.civilaffairsassoc.org/ html/CAA_Article_Origins.pdf (accessed 9 January 2014), 4.

${ }^{24}$ Civil-Military Cooperation Centre of Excellence, 6.

${ }^{25}$ Donnison, 296.

${ }^{26}$ Coles and Weinberg, 10.
} 
In early 1942, the Provost Marshal General Office derived the framework of a deliberate system for the occupation of foreign territories and governance, using the British example as a basis. The ideal type of military governance is an organization that incorporates the local laws, institutions, customs and economics under a competent military control with intention of eventual civilian control. ${ }^{27}$ To add further substance through education, the School of Military Government was opened at the University of Virginia in Charlottesville in May of $1942 .{ }^{28}$ Starting small, the initial graduating class consisted of only 50 senior officers. Subsequently, 200 officers went through the program every three months. ${ }^{29}$ The school's leadership scoured various universities for faculty, canvassed other government departments for lecturers, and hired three key experts for Germany, Italy and Japan. ${ }^{30}$ Dr. Arnold Wolfers from Yale, Johns Hopkins, and Dr. Hugh Borton from Harvard, helped shape the graduates' understanding of the cultural and social aspects of military governments with respect to the various theaters. ${ }^{31}$ The American accelerated course covered a curriculum ranging from martial law and military governments, and general principles of public administration. Additionally, graduates received cultural and language training for a period up to six months, at recognized universities such as Yale, Harvard and Stanford. ${ }^{32}$ Much later in the African theater, a joint civil affairs school established by Allied Forces Headquarters (AFHQ) in Algiers, trained British and American CAOs together for the Sicilian invasion and the

\footnotetext{
${ }^{27}$ Daugherty and Andrews, 194.

${ }^{28}$ Coles and Weinberg, 11.

${ }^{29}$ Ibid.

${ }^{30}$ Earl Ziemke, “Civil Affairs Reaches Thirty,” Military Affairs 36, no. 4 (December 1972): 132.

${ }^{31}$ Ibid.

${ }^{32}$ Civil-Military Cooperation Centre of Excellence, 7.
} 
eventual occupation of Italian towns, cities, and provinces under AMG. ${ }^{33}$ The joint civil affairs school was developed for the deliberate crosstraining of British and American CAOs and to provide the last opportunity for training before the invasion.

The first commandant of the School of Military Government quickly recognized the insufficiency of curriculum at Charlottesville to serve as stand-alone source for civil affairs and military government instruction. In a memorandum to the Provost Marshall General, the Commandant, BG Cornelius Wickersham identified the larger need for a robust operation of military governance in preparation for the conflict in Europe. ${ }^{34}$ While jockeying for military dominance, BG Wickersham called for the rapid commissioning of qualified civilians as CAOs, to execute military governance in enemy territory. BG Wickersham envisioned drawing civilian expertise from within the United States and applying their efforts in support of the ground commander. He called for a deliberate increase of technical and administrative specialties, foreseeing the challenges facing military governments. BG Wickersham argued that even the limited occupation of Germany after WWI relied extensive of civilian administration, which facilitated a much smaller civil affairs footprint within formations ${ }^{35}$ Similarly, the United Kingdom also attempted to recruit and train civilian experts for this purpose and alleviate the training requirement with real world experience. The British War Office recruited civilians for the revised Civil Affairs Staff Centre, to train civil affairs and relief officers for the period of military responsibility and for the subsequent period when civil authorities resumed control. ${ }^{36}$ The Civil

\footnotetext{
${ }^{33}$ Walter F. Goodman, Jr., Excerpt of An Autobiography and Memoirs of Walter F. Goodman, Jr., A Soldiers Story, Civil Affairs Association, http://www.civilaffairsassoc.org/pdf/col_goodman_ memoirs.pdf (accessed 24 February 2014), 48.

${ }^{34}$ Coles and Weinberg, 12.

${ }^{35}$ Donnison, 17.

${ }^{36}$ Ibid., 297.
} 
Affairs Staff Centre's curriculum for military governments only addressed the international conventions for the occupation of enemy territory. The policy was not adequately defined for operations in neutral, quasi-neutral or co-belligerent territories in the two institutions. This insight by BG Wickersham in June 1942 augured the future challenges facing the AMG personnel in post-Fascist Italy the following summer.

Underscoring the need for finality in the scope for civil affairs was the defining of how it can best support the overall strategy of the Allies. With each Allied partner shaped by post WWI experiences with Germany, Britain, Russia and the United States, all approached their respective strategy from different perspectives. By the end of 1941, Great Britain was deep in the conflict, haunted by the losses of WWI and the retreat from Dunkirk, feeling isolated and alone in Europe. Prime Minister Churchill expressed his and his nation's convictions, favoring indirect action and not committing to a large-scale invasion until Britain achieved overwhelming numerical superiority. ${ }^{37}$ Premier Joseph Stalin and the Soviet Union entered the strategic discussion with a general underlying suspicion of its capitalist allies. From its perspective, the closeness of the Anglo-American partnership and the delay of opening a second front in Europe solidified its conspiracy thoughts that the West intended to bleed the Soviets dry of its military might. ${ }^{38}$ Premier Stalin and Soviet planners demanded a second front, while holding a defensive position in the East and interpreting any postponement as proof of the conspiracy. American strategists feared premature Soviet departure and attempted to appease the British and Soviets by playing the middleman. The British also feared American abandonment of Europe, at least initially, turning all United States efforts to face Japan. ${ }^{39}$ Despite the surprise attack on Pearl Harbor, an inherent

\footnotetext{
${ }^{37}$ Gaddis Smith, 5 .

${ }^{38}$ Ibid.

${ }^{39}$ Ibid., 24.
} 
sense of optimism persevered, based on the United States' experience in WWI. Despite dramatic losses, the relatively short American experience exuded positivity and confidence, with U.S. forces entering the war in the summer and victory was at hand by November. This optimistic confidence, led President Roosevelt and American planners to favor a strategy of eliminating the most powerful Axis adversary first. This was reflected in the debate with the British Government about a cross-channel operation. ${ }^{40}$ The Declaration of the United Nations on New Year's Day 1942, cemented the United States' commitment to its allies in Europe:

Being convinced that complete victory over their enemies is essential to defend life, liberty, independence and religious freedom, and to preserve human rights and justice in their own lands as well as in other lands, and that they [the signatory countries, to include U.S., U.K., and Soviet Union] are now engaged in a common struggle against savage and brutal forces seeking to subjugate the world. ${ }^{41}$

The Declaration of the United Nations is important to civil affairs and military governance in its language regarding complete victory. This strategic messaging foreshadowed the eventual call for unconditional surrender of the Axis parties and tinted all future planning for the occupation and post-victory governance.

In January 1941, the British were embroiled in political discourse between the War Office and Whitehall over who would best direct in the civil affairs mission. In the discourse, the political administrators called for administrative and financial responsibility under the civilian system, specifically the Colonial Office, due to its specialized knowledge and experience. ${ }^{42}$ However, the military opposed to the political administrators arguing the CinC should have responsibility for occupation and administration. The British War Cabinet resolved the debate

\section{${ }^{40}$ Gaddis Smith, 2.}

${ }^{41}$ The Avalon Project, Declaration of the United Nations, January 1, 1942, Lillian Goldman Law Library, Yale Law School, http://avalon.law.yale.edu/20th_century/decade03.asp (accessed 23 March 2014).

\footnotetext{
${ }^{42}$ Donnison, 22.
} 
with the Colonial Office on February 20, 1941, awarding the military sole possession of the military governance mission, citing that one department, and one department only, must be responsible for the administration of foreign territories. ${ }^{43}$ Unlike the British decision, President Roosevelt initially decided, that civil affairs operations were best handled under complete civilian control, generated confusion in preparation for military governments. There was no hiding the President's criticism of the School of Military Government and military administration on foreign soil. In a memorandum from President Roosevelt to Secretary of War on October 29, 1942, the President stated, "I understand that the Provost Marshal General is training a substantial number of men from civil life to assume the duties of Military Governor or civilian advisors to Military Governors of occupied territories. I should like to have from him a complete explanation of the project. The governing of occupied territories may be of many kinds but in most instances it is a civilian task and requires absolutely first-class men and not second-string men." ${ }^{44}$ Reluctantly, the American Government eventually reached the conclusion to divide any occupied hostile or Axisheld territory into two distinct phases. The first phase was that of military necessity, immediately following combat operations. The second phase, commenced when hostilities ceased and military necessity was no longer required. Then civilian authority could be established. ${ }^{45}$ These two broad phases overlapped along a conditions-based timeline as the Army surrendered control to civilian authority. While disputed in the military government community, the highest War Department leaders supported this concept. Simply put, the transfer to civilian authority alleviated the strain on Army resources and personnel to focus on other operations. The political undertones and fears

\footnotetext{
${ }^{43}$ Donnison, 23.

${ }^{44}$ Coles and Weinberg, 22.

${ }^{45}$ Ibid., 19.
} 
of incompetence of the military authority continued to plague the effectiveness of preparations for occupation.

The debate for the lead in civil affairs continued between civil agencies and the military government planners, prior to Operation Torch. The Lend-Lease Administration, under the supervision of the U.S. Department of State, had been charged by President Roosevelt with providing food and other essentials for all occupied territories. ${ }^{46}$ To further coordinate the relief activities, special liaisons were established between the War Department and State Department, with a designated representative to act as the commanding general's civil advisor. ${ }^{47}$ As the operations in North Africa expanded, the need for civil administration became apparent. However, the application of the two broad phases for governance and the transfer authority from military to civilian authority remained unclear. As seen repeatedly in the subsequent operations in Italy, these political decisions and strategic implications created additional problems for the military in this arena. In its inaugural run, the Civil Affairs Section, headed by Robert D. Murphy, a former Counselor of the American Embassy at Vichy, was directed to rapidly establish administrative responsibility for the North African territory. Additionally, President Roosevelt explicitly directed the cooperation of the military and civilian agencies with the French. The United States elements of civilian authority were unable to mobilize with adequate resources to truly affect operations initially, leaving only a military solution. In a letter from President Roosevelt to Secretary Stimson on June 3, 1943, the President clearly expresses his intention for the maximum utilization of civilian resources and eventual civilian control of civil affairs operations, despite initial difficulties in execution. President Roosevelt wrote,

\footnotetext{
${ }^{46}$ Coles and Weinberg, 38.

${ }^{47}$ Ibid.
} 
I am convinced that they [civilian agencies] should be brought into operations at the earliest stage of occupation consistent with military considerations and that maximum reliance should be placed in their work.

Total war, as our enemy has demonstrated, involves full use of military and civilian resources. The civilian agencies have considerable experience and talent that it would be difficult and undesirable for the Army to duplicate ...

Accordingly, I want your Civil Affairs Division and other parts of the Service to work with these agencies in closest cooperation and to use them to the maximum extent possible. This will leave you free to carry on the primary task which your are facing - the execution of military operations against the enemy. ${ }^{48}$

The American and British political circles did not wholly welcome the arrangement with the Vichy French, later to be known as the Darlan Deal, established by LTG Eisenhower and Mr. Murphy. Many British retained ill feelings towards the Vichy French, who had essentially aligned themselves with Germany. Acting under the guidance of a military commander, LTG Eisenhower saw the establishment of a Vichy French system as a primarily military necessity, that the Allies "could not afford a military occupation, unless we [Allied Forces] chose to halt all action against the Axis." ${ }^{49}$ With no other choice, the United States Administration decided to accept at face value whatever French system left in place in French North Africa, and based all military government operations around it. At the Casablanca Conference, President Roosevelt confronted Mr. Murphy specifically on the long-lasting commitments of the Darlan Deal saying "But you overdid things a bit in one of the letters you [Murphy] wrote to Giruad [French General in North Africa] before the landings, pledging the United States Government to guarantee the return to France of every part of her empire. Your letter may make trouble for me after the war." ${ }^{50}$ The deal with ADM Francois Darlan, called for French governmental personnel to continue the basic administrative functions with direct support from LTG Eisenhower's forces, as coordinated

\footnotetext{
${ }^{48}$ President Roosevelt to Secretary Stimson, quoted in Daugherty and Andrews, 227.

${ }^{49}$ Daugherty and Andrews, 206.

${ }^{50}$ Robert D. Murphy, Diplomat Among Warriors: The Unique World of a Foreign Service Expert (New York, Doubleday and Company, 1964), 168.
} 
through Mr. Murphy's civilian Civil Affairs Section. Additionally, it essentially tied the United States to the longstanding support and protection of France upon its liberation.

\section{$\underline{\text { PLANNING FOR THE OCCUPATION OF ITALY }}$}

The immediate lesson made apparent by the invasion of North Africa is that military commanders were directly involved in civil affairs operations on a much greater scale than envisioned by all parties, American and British. ${ }^{51}$ In Field Marshal Lord Alan Brooke's memoirs, he recalled how LTG Eisenhower was deeply involved with the politics of occupation of North Africa rather than strictly military operations. Field Marshal Brooke wrote, "I am afraid that Eisenhower as a general is hopeless! He submerges himself in politics and neglects his military duties." 52 This sentiment was echoed by MG John Lucas who was sent by General George Marshall, Chief of Staff of the Army, to aid LTG Eisenhower in separation of political and military duties. According to MG Lucas, General Marshall stated, "he had found what he considered to be a very serious, a very dangerous, situation in that Eisenhower was so immersed in the political side of his job that he had little or no opportunity to keep in touch with the troops under his command." 53 The magnitude of civil affairs operations in North Africa was much greater draw on the attention of military leaders than had been expected, and the draw began to affect military operations.

Following the stumbles in North Africa, the Combined Chief of Staffs (CCS) and the political leaders of the United Kingdom and the United States called for a more definitive plan for the occupation of Italy. For the military, this North African involvement emphasized the

\footnotetext{
${ }^{51}$ Daugherty and Andrews, 220.

${ }^{52}$ Alan Brooke, War Diaries: 1939-1945, Alex Danchev \& Dan Todman, eds. (Berkeley, CA: University of California Press, 2001), 351.

${ }^{53}$ MG John P Lucas, From Algiers to Anzio, typescript, John P. Lucas Papers, Box 6, Military
} History Institute, Carlisle, PA. 
difficulty to separate military operations from political context. Experiences in North Africa also identified the need for combined machinery to coordinate the efforts for civil affairs and military governance between the United States and United Kingdom. The coordinated efforts of the United States Civil Affairs Division in Washington and the United Kingdom Civil Affairs Directorate in London would have to be more integrated going forward.${ }^{54}$ Specifically addressing civil affairs coordination between the two countries, the CCS established the Combined Civil Affairs Committee in July 1943, in order to act as the planning element for the CCS on all areas regarding occupation and military governance. ${ }^{55}$ The CCS further assigned the responsibility of military government to the AFHQ under LTG Eisenhower, after the civilian agencies failed to overcome the logistical issues experienced in North Africa.

Civilian attempts to provide supplies for civilian relief under the Office of Foreign Relief and Rehabilitation Operations and later under the United Nations Relief and Rehabilitation Administration were plagued with difficulties. Competing intentions overlaid with ineffective bureaucracy greatly weakened the appointed civilian Governor Henry Lehman, already the head of the State Department's Office of Foreign Relief and Rehabilitation Operations (OFRRO) in North Africa ${ }^{56}$ In a War Department meeting on June 4, 1943, Governor Lehman's difficulties in procuring supplies was discussed in detail. The following aspects were stated during the briefing His [Governor Lehman] position is largely dependent on the Army. He has, in fact, no authority, save letter from President, and no funds. The Army, in short, must support his program of requirements, but it is doubtful whether the War Department can undertake to certify his needs

\footnotetext{
${ }^{54}$ Donnison, 23.

${ }^{55}$ Ibid., 68.

${ }^{56}$ Coles and Weinberg, 99.
} 
while doubt remains as to ultimate responsibility. ${ }^{57}$ The Army was given accountability essentially by political default since the U.S. State Department was unable to produce a viable administrative system at the given time. The civilian system that was established in North Africa was established for civilian relief and the distribution of aid through the Vichy French administration. It was determined by military leaders in North Africa and in Washington that the performance of supply functions by civilian agencies in a theater of war had not proved entirely satisfactory. The military had too little control over a function (shipment of supplies) which could seriously affect their operations going forward. ${ }^{58}$ In a letter from President Roosevelt to Secretary of War Stimson on November 10, 1943, the apprehension in the Army's control is quite clear. President Roosevelt wrote, "Although other agencies of the Government are preparing themselves for the work that must be done in connection with the relief and rehabilitation of liberated areas, it is quite apparent if prompt results are to be obtained the Army will have to assume the initial burden." ${ }^{59}$ The President continued, "Therefore, I direct that you have the Army undertake the planning necessary to enable it to carry out this task to the end that it shall be prepared to perform this function, pending such time as civilian agencies must be prepared to carry out the longer range program of relief." ${ }^{\circ 0}$ The military interpretation of the Presidential directive, by LTG Eisenhower and AFHQ, greatly changed the application of military resources and the Allies' priorities as it applied to Italy.

The monumental level of logistics required for relief of occupied areas became the biggest draw of Allied resources and transport systems. Seen early on as an additional constraint

\footnotetext{
${ }^{57}$ Coles and Weinberg, 105.

${ }^{58}$ Komer, 69.

${ }^{59}$ Coles and Weinberg, 108.

${ }^{60}$ Ibid., 109.
} 
for Allied planners and commanders, the relief effort ballooned through the Italian war effort to unforeseen levels. As construed by planners in November 1943, this political directive has "added the responsibility of organizing and commencing the shipping and distribution of relief supplies in liberated areas" and "whether or not the areas are occupied by military forces." change in policy had lasting implications for military operations in Italy and later Europe. The planning estimates and forces were developed using the following hypotheses: (1) that German resistance collapsed without the execution of a Scorched Earth policy; (2) that German resistance collapsed after execution of such a policy; (3) that a successful yet contested Allied invasion yielded the adoption of a Scorched Earth policy by the Germans. ${ }^{62}$ Allied relief efforts were envisioned to be minimal with heavy use of indigenous administrations for the distribution of relief supplies. While hesitant to adopt responsibility for relief operations wholly, it was clear that the British depended largely upon the Americans to provide the resources. Additionally, it was unacceptable to the political leadership of the U.S. and U.K. for the two nations to execute different relief policies under a unified Supreme Commander. ${ }^{63}$ It was discovered by the CAOs responsible for execution in the Italian campaign, that civilian relief operations addressed every aspect of the planning estimates, to a scale that exceeded all expectations.

While the Allied focus remained in combat against the failing Italian Army and German Forces in the Mediterranean, the political direction to establish civil control and relief for all liberated areas was resounding. The ramifications for the military are best summed in a letter to GEN Hilldring, Chief of the Army's Civil Affairs Division, from COL Bendenton, Chief of Staff, G-5 for Chief of Staff for Supreme Allied Commander, in which COL Bendenton wrote,

\footnotetext{
${ }^{61}$ Coles and Weinberg, 109.

${ }^{62}$ Donnison, 150.

${ }^{63}$ Ibid.
} 
However, if you accept that military objective [the entrance into and the deployment of our forces for an effective occupation of Germany] without reservation as a basis for your civil affairs policy, you will go astray, because the civil affairs mission of an Army is compounded of political, economic, fiscal, relief, and social considerations that do not enter into the determination of the military mission. It appears to me from this and from previous letters that you are attempting to confine your responsibilities to the zones through which our troops advance. The proper conception, in my opinion, of the civil affairs mission is to state that we civil affairs fellows are responsible for the wake of battle. Any other conception will lead us into trouble. It is, in my opinion, highly erroneous to feel that we are only responsible for those acres of ground on which a combat soldier has previously set foot. We are responsible for the areas liberated as a result of military operations or by the voluntary withdrawal of hostile forces under the threat of military operations. ${ }^{64}$

In this message, COL Hilldring eloquently highlighted that Allied Forces could not waive the requirements for relief and stability operations in the future. In order to meet the military mission, civil affairs would be applied whole-heartedly. The implication of civil affairs planning for future operations in the war loomed in every aspect of preparations. Additionally, the special circumstances seen in Italy greatly complicated issues for the Civil Affairs Division. Civil affairs and military government operations in Italy differed significantly from North Africa. This was largely due to the direct involvement and demands of the political powers within the United States and United Kingdom.

At the Casablanca Conference in January 1943, President Roosevelt and Prime Minister Churchill concluded that Sicily would be the point of the invasion following action in Tunisia. Growing from the tension between the Anglo-Americans and Premier Stalin over the promised second front against Germany, the friction between military and political choices around Casablanca were severe. With the Premier abstaining from the conference, the President Roosevelt and Prime Minister Churchill delved into the guidelines for the next stage of the military campaign, each with their own political motivations. While the United States strategists

${ }^{64}$ Letter from COL Hilldring, Civil Affairs Division to Chief of Staff Supreme Allied Commander, 8 December 1943, Dwight D. Eisenhower Library Collection of 20th Century Military Records, Dwight D. Eisenhower Presidential Library and Museum, Abilene, KS, ser 3, box 12. 
saw the Mediterranean as "a temporary battleground and little more," the British saw the Mediterranean as an "essential link in their imperial system." while referred to as a compromise, clearly favored British interests and pulled American resources from their intended cross-channel attack for over a year. The U.S. members of the Combined Chiefs of Staff feared the British approach would negatively affect America's military position and national policies in the Far East and, with them, Washington's ability to pursue a Europe-first strategy in the future. ${ }^{66}$

Tied to the larger military implications of resources regarding a cross-channel attack, civil affairs planners in support of the AFHQ faced a logistical problem much larger than that in North Africa. The quantity of enemy was much greater than seen in the Vichy French controlled territory and Sicily was much more densely populated than North Africa. From the initiation of operations, President Roosevelt called for the unconditional surrender of the Axis Powers (to include Italy) and the complete removal of the Fascist Administration in power. This political motivation required the nearly complete removal of the legal and administrative systems within Italy that had been subjugated to Fascist control for the last twenty years. Prime Minister Churchill stated in June 1943:

We, the United Nations, demand from the Nazi, Fascist, and Japanese tyrannies unconditional surrender. By this, we mean that their will power to resist must be completely broken, and that they must yield themselves absolutely to our justice and mercy. It also means that we must take all those far-sighted measures which are necessary to prevent the world from being again convulsed, wrecked and blackened by their calculated plots and ferocious aggressions. It does not mean, and it never can mean, that we are to stain our victorious arms by inhumanity or by mere lust of vengeance, or that we do not plan a world in which all branches of the human family may look forward

\footnotetext{
${ }^{65}$ Murphy, 167.

${ }^{66}$ Stoler, 111.
} 
to what the American Constitution finely calls 'life, liberty, and the pursuit of happiness. ${ }^{67}$

By placing the Prime Minister's speech in the context of operations within Sicily and soon the Italian mainland, it is clear that the underlying intention of military governance was to foster a new Italy in place of the former. Despite Prime Minister Churchill's rhetoric about the U.S. Constitution, differences remained between the American and British policy makers as to how the Italian state should be restructured or reconstituted. Additionally, Sicily and the Italian mainland were significantly more populated and developed as a modern state than French North Africa. Governance and administration requirements for this operation greatly strained military resources, surpassing requirements in North Africa. Lastly, the political relationship between British interests and American interests for Italy played a direct role in the application of military government as an Allied force. For instance, Prime Minister Churchill, throughout the preparation and execution, placed political pressure in favor of saving the throne for King Emmanuel III, if possible. Removing Italy from the war was not necessarily directly associated with removing the monarchy from Italy. President Roosevelt, while not in direct support of the King, was supportive of Prime Minister Churchill, which led to the military acceptance of the Italian monarchy.

Unlike civil affairs operations following WWI, President Roosevelt and Prime Minister Churchill called for one integrated system of combined responsibility for military governance throughout the area of operations. This combined effort was distinct from the zonal framework established in WWI and what would be established following the defeat of Nazi Germany. Additionally, in the execution of the integrated system every aspect would be largely political driven as the interests of three nations (Italy, United States and United Kingdom). This amalgamation of American and British civil affairs efforts, from the headquarters to tactical level,

\footnotetext{
${ }^{67}$ Winston S. Churchill, Speech at Guildhall, 30 June 1943, in Onwards to Victory: War Speeches by the Right Honorable Winston S. Churchill, C.H., M.P., compiled by Charles Eade (Boston: Little, Brown and Company, 1944), 169.
} 
foreshadowed combined operations today. COL Goodman, an American CAO serving in the

British Eighth Army, recalled the joint aspect applied to the mission:

One of the strategies was to mix commands with British and American officers. A small contingent of British officers were assigned to work with the American Fifth Army in Italy and another small contingent of American officers was assigned to work with the British Eighth Army in Italy ... I stayed with the British Eighth Army until the end of combat in Italy. Since I was assigned to the Eighth Army I wore the "Crusader" patch for the rest of the war. ${ }^{68}$

In February 1943, LTG Eisenhower put forth his own thoughts on how to best apply joint

operations in Sicily and Italy, in a message to the War Department. Noting the unprecedented

action about to take place, LTG Eisenhower stated:

This is the first United States operation involving the invasion and occupation of enemy territory. It is the first British operation involving the invasion and occupation of enemy territory other than colonial. It is as well the first joint operation against enemy territory. It will inevitably establish precedents far-reaching in scope and operations importance and will set the pattern for later operations in Europe. ${ }^{69}$

Newly promoted, General Eisenhower and the AFHQ understood the political interests of both the United States and the United Kingdom was superior to military operations within Italy.

Both nations wished to mold its own character on occupation and governance to best suit its interests in the region. Since the United Kingdom held a more direct interest in the Mediterranean, the political leadership called for position as the senior effort. Since the United States took the lead in civil affairs in North Africa, many British political elites thought the roles should be reversed for the follow-on campaign. ${ }^{70}$ However, the United States State Department urged a stronger American presence in civil affairs to better exploit the strong pro-American

\section{${ }^{68}$ Goodman, 49.}

${ }^{69}$ Message from General Eisenhower, Supreme Allied Commander to War Department, 8 February 1943, Dwight D. Eisenhower, Pre-Presidential Papers, 1916-1952, box 22, Dwight D. Eisenhower Presidential Library and Museum, [Hereafter DDEL].

${ }^{70}$ Komer, ch. 2, 4. 
feeling in Sicily and southern Italy. ${ }^{71}$ After months of political dialogue, the recommendations from GEN Eisenhower for a Joint Anglo-American effort of both United Kingdom and United States planners led to the creation of the Combined Civil Affairs Committee in July $1943 .{ }^{72}$ The Combined Civil Affairs Committee assumed the responsibility for the planning and execution of civil affairs on behalf of both the United States and United Kingdom interests, as a combined effort in support of the CCS and intermixed British and American planners in nearly all capacities.

The planning efforts for Operation Husky called for the direct military government under the Allied Military Government of Occupied Territory (AMGOT) in Sicily. It was a combined effort between United States and United Kingdom. AMGOT began operations without direct oversight from the Combined Civil Affairs Committee, but reported instead through the tactical command and control organization of the Seventh and Eighth Armies, often resulting in a disorganized effort. The command and control organization and reporting structure for civil affairs and military governance demonstrates how AMG differed from other territories in the war. As directed by AFHQ the "purpose of AMGOT will be to administer the Allied Military Government under the Military Governor of the territory in accordance with rules and usage of international law." 73 Those assigned to AMGOT held the general responsibility subordinate to the military commanders on the ground, and in support of their combat operations against Italian and German Forces. Specifically in Sicily, the broad objectives developed for AMGOT included the following:

(1) to insure the security of the occupying forces and their lines of communication and to facilitate military operations;

\footnotetext{
${ }^{71}$ Komer, ch. 2, 5 .

${ }^{72}$ Ibid., 9.

${ }^{73}$ Coles and Weinberg, 182.
} 
(2) to restore law and order and normal conditions among the civil population as soon as possible, to procure the necessary food supplies for it, and, when necessary, to provide relief and maintenance for destitutes within available resources;

(3) to relieve combat troops of the necessity of providing for civil administration;

(4) to assist in making available to the occupying forces the economic resources of the captured territory; and

(5) to promote the political and military objectives of Allied Forces in connection with future operations through the efficient government of the territory and by the application of the CinC's (Commander in Chief) policies toward the civilian population. ${ }^{74}$

The subordination of civil affairs and military government operations to combat operations was paramount for all involved but the repercussions of inadequate preparations had direct influence on the Allied Forces tactical operations as well. As depicted in the revisions of FM 27-5, United States Army and Navy for Military Governance, published in December 1943, "The first consideration at all times is the prosecution of the military operation to a successful conclusion. Military necessity is the primary underlying principle for the conduct of military government."75 The struggle between military necessity and the need for governance and relief, created a perpetual tension throughout the Italian campaign. Unlike Germany, and later Japan, who ultimately surrendered before military government was established the campaign in Italy called for continued military necessity as the combat operations continued until 1945 .

Of direct political implication to AMGOT operations was the Combined Chiefs of Staff's adoption of a policy of benevolence in the military government for Sicily. Although AMGOT continued the removal and internment of prominent Fascist leaders and Nazi sympathizers, it would be conducted in way for the betterment of Italian people. ${ }^{76}$ This realistic approach to the planning for occupation relieved some of the pressure for the AFHQ and removed the requirement for the creation of an entirely new system of governance. Far more complex than the

\footnotetext{
${ }^{74}$ Komer, ch. 2, 13.

${ }^{75}$ US Army and US Navy, Field Manual 27-5, United States Army and Navy for Military Governance and Civil Affairs (Washington, DC: US Government Printing Office, December 1943), 7.

${ }^{76}$ Komer, ch. 2, 10.
} 
French Administration in North Africa, AMGOT utilized current systems and legal structures to establish military governance following the removal of the Fascist predecessors. The utilization facilitated basic operations without interfering with combat forces. The CCS directive for the Organization and Operation of Military Government for Husky established the general policy on June 28, 1943. The directive states that AMGOT "shall be benevolent with respect to the civilian population so far as consistent with strict military requirements. It should be made clear to the local population that military occupation is intended: (1) to deliver people from the Fascist regime which led them into the war; and (2) to restore Italy as a free nation."77 This overarching directive and supporting guidelines defined the AMGOT mission and requirements to meet the needs of the people in occupied territories, remove Fascists and Nazis from control and influence, and eventually establish a system of sustainable civil security and services for a free Italian people.

Leading into the invasion of Sicily, the Allies defined and agreed upon the task organization of AMGOT. It was imperative that AMGOT remained responsible directly to the Commander in Chief GEN Eisenhower, for all guidance on political questions that arose during the occupation. General Sir Harold Alexander was assigned the responsibilities as the Military Governor for Sicily. Carrying on the balancing between British and American leadership, AMGOT contained an even mixture of American and British personnel, mostly recruited from their respective schools of military government and civilian expertise. Civilian specialists were also commissioned and assigned to AMGOT in the fields of public utilities, police, public health, public welfare, and other fields important to civil administration. ${ }^{78}$ Growing to approximately 400 officers and 500 enlisted men, AMGOT served in coordination with Seventh and Eighth Armies' Headquarters through the Senior Civil Affairs Officer. Additionally, the CAOs and staffs

\footnotetext{
${ }^{77}$ Coles and Weinberg, 177.

${ }^{78}$ Komer, ch. 2, 29.
} 
integrated into the assault force and established crucial systems of administration as deploying forces seized territory and population centers. Like a rolling tide, CAOs established local and provincial military governments as the frontline pushed deeper into Sicily.

On June 18, 1943 the AFHQ established the Military Government Section (MGS) as its element into the process of AMGOT. ${ }^{79}$ The MGS served as the tool for broader administrative control for the Allied CinC over military government in Sicily and in future operations. Its major responsibilities included the direction and coordination of military government planning, advising on policy matters, and acting as the CinC executive in the issuance of directives to subordinate headquarters. ${ }^{80}$ Similar to the role of the Combined Civil Affairs Committee to the CCS, MGS contained the expertise for AFHQ's execution of policy in Italy.

\section{CIVIL AFFAIRS IN MILITARY GOVERNANCE IN SICILY}

Three formal declarations announced the basis for the role of Allied Forces on Sicily to the Italian people. The first was a proclamation from GEN Eisenhower made on July 10, 1943, following the successful invasion of Seventh and Eighth Armies, under the combined $15^{\text {th }}$ Army Group. In GEN Eisenhower's proclamation, the Allied Forces declared themselves as liberators of an oppressed Italy. GEN Eisenhower proclaimed, "You will be beneficiaries of their [Axis Leaders/German Occupiers] defeat. It is therefore your interest, as men whose fathers fought for their freedom, not to resist the Allied army, but to facilitate their mission - the lifting of the Nazi yoke from Europe by quick and total victory." ${ }^{11}$ The second message was the AMGOT proclamation from General Alexander, Military Governor, regarding the execution of military government in occupied areas and the role of the newly "liberated" Italian people beneath it. It

\footnotetext{
${ }^{79}$ Coles and Weinberg, 184.

${ }^{80}$ Komer, ch. 2, 32 .

${ }^{81}$ Proclamation of General Eisenhower (SAC) on Invasion of Sicily, 10 July 1943, Eisenhower Library Collection, ser. 3, box 12, DDEL.
} 
stated in Article I, “All powers of government and jurisdiction in the occupied territory and over its inhabitants, and final administrative responsibility are vested in me as General Officer Commanding and Military Governor and the AMGOT is established to exercise these powers under my direction." $\$ 2$ The third message was a combined message from President Roosevelt and Prime Minister Churchill, delivered to the Italian people on July 16, $1943 .{ }^{83}$ The political communique placed the onus for the war on Mussolini. Isolating the blame of the war effort from the Italian populace, the third proclamation created the basis for separating Italy as it stood then, from the actions of its previous ruler. President Roosevelt and Prime Minister Churchill stated, "Mussolini carried you into this war as the satellite of a brutal destroyer of peoples and liberties. Mussolini plunged you into a war which he thought Hitler had already won ... All your interests and all your traditions have been betrayed by Nazi Germany and your own false and corrupt leaders" ${ }^{\prime 4}$ From the CinC, the essence of the proclamations established the benevolent approach of the Allied Forces to the Italian people. Declaring, "Allied forces are occupying Italian territory. They are doing this not as enemies of the Italian people, but as an inevitable part of their war to destroy the German overlordship of Europe. Their [Allied Forces] aim is to deliver the people of Italy from the Fascist Regime which led them to war, and when that has been accomplished, to restore Italy as a Free Nation." 85 Additionally, GEN Eisenhower's message prohibited all political activities during the period of military government, essentially taking the first step to remove Fascist control of the occupied territories. Along the same theme as GEN Eisenhower's

\footnotetext{
${ }^{82}$ Allied Military Government of Occupied Territory Proclamation, excerpt from AMGOT Plan,
} 12 July 1943, Eisenhower Library Collection, ser. 3, box 12, 28-30, DDEL.

${ }^{83}$ Harris, 31.

${ }^{84}$ Churchill, 178.

${ }^{85}$ Coles and Weinberg, 190. 
proclamation, General Alexander proclaimed his authority and the authority of the AMG and called for peaceful order by all Italians under its influence.

Combined, the proclamations declared that the Allied Forces were not enemies of the Italian people, but are acting as liberators from Fascism and Germany tyranny, with the intention of restoring Italy to its former prestige. The AMGOT proclamation removed the Italian civil and criminal courts, but retained all administrative and judicial officials to maintain civil operations throughout the provinces. The administrative system incorporated its services under the direction of Allied Forces, specifically the local and provincial CAOs within Seventh and Eighth Armies. ${ }^{86}$ The strategic messaging from President Roosevelt and Prime Minister Churchill called for the Italian people to remove themselves from the shameful leadership of Mussolini and his Fascist regime that misled the Italian people into a costly and unwinnable war. ${ }^{87}$ Additionally the message stated, "the sole hope for Italy's survival lies in honorable capitulation to the overwhelming power of the military forces of the United Nations." 88 The proclamations created a system, for better or worse, where all elements of civil control for the Italian people were centered on the CAO. Supplemented by the Allied invasion of the poorest parts of Italy, this central focus for the Italian need for food, shelter and security, ultimately created a dependency on AMGOT that ultimately slowed the effectiveness of the transfer back to Italian control. Reciprocated in the recent efforts in Iraq and Afghanistan, the intentions of civil control by an outside occupying force essentially stifles the need to speedily develop governance on their own.

Despite the best interests and planning efforts before the invasion, serious problems arose in the execution of military government in Sicily. Most were unforeseen but some were due to the

\footnotetext{
${ }^{86}$ Coles and Weinberg, 190.

${ }^{87}$ Harris, 31 .

${ }^{88}$ Ibid.
} 
administrative and logistical system created inside the AMGOT organization. In regards to Sicily, two major problems caught the CAOs unprepared at all levels, including a shortage of food supplies and the speed of Allied advance. Most seriously, planners failed to account for the massive food shortage in Sicily. As combat operations and maneuver formations traversed the Sicilian countryside, they destroyed entire crops. The lack of foodstuffs quickly translated more predominately in the urban centers and became a paramount concern for AMGOT in nearly all regions. The shortage of food resulted in two major effects handled by the local CAOs. The first produced a spike in black market activities and growing dissatisfaction with military government control by local Sicilians. The black market offered farmers a way to bypass the fixed prices for their goods established by the AMGOT. This criminal element then created unrest and the need for additional resources from the military police sections and local carabinieri (AMGOT sponsored Italian police force) to emplace roadblocks and check points to mitigate the black market activity. Second, the inability to fulfill perceived promises made in Allied propaganda dwindled Italian support for the occupying force over time. ${ }^{89}$ Discontent quickly grew within the population centers, as overworked and understaffed CAOs struggled to maintain domestic obedience and order. AMGOT was also unprepared for the rapid advance of the ground forces across Sicily.

The American and British advances swiftly moved through the western areas, reaching major population centers within a few days after the landing. Within two weeks, LTG Patton's forces had reached the city of Palermo along the northern coast. The AMGOT faced the challenge of rapidly occupying Italian provinces with such speed that civil affairs operations failed to establish governance in one town before moving onto the next. In a memorandum from MGS Liaison, LCDR MacLean described the Hit-and-Run operations adopted by many local and

\footnotetext{
${ }^{89}$ Komer, ch. 2, 39.
} 
provincial CAO teams. LCDR MacLean reported, "He [the Civil Affairs Officer] would then gather about him such town officials as remained, tell the story of their liberation, outline to them the essential features of military government and what the civilians were expected to do and not to do, call their attentions to the proclamations, and dismiss them until a later designated time." $" 90$ Passing on the message and information regarding civil affairs programs, the local CAO traveled onto the next town and began the process anew. This drive-by military government continued for several weeks, until the establishment of official AMG Headquarters under the Military Governor at the end of July. Additionally, in some cases, CAOs took towns before the actual arrival of combat troops. ${ }^{91}$ The sheer tempo of combat operations forced AMGOT personnel and leadership to respond sinuously to the ever-changing landscape and quantity of territory occupied. After Messina fell and Sicily was conquered on August 17, 1943 (thirty-nine days following DDay), AMGOT now controlled territory of 9,923 square miles (roughly the size of Massachusetts), containing nine provinces and 357 communes, and a population of more than four million Italians to care for. ${ }^{92}$

\footnotetext{
${ }^{90}$ Coles and Weinberg, 195.

${ }^{91}$ US Army, Review of Allied Military Government and of the Allied Commission in Italy, 10. ${ }^{92}$ Ibid., 11 .
} 


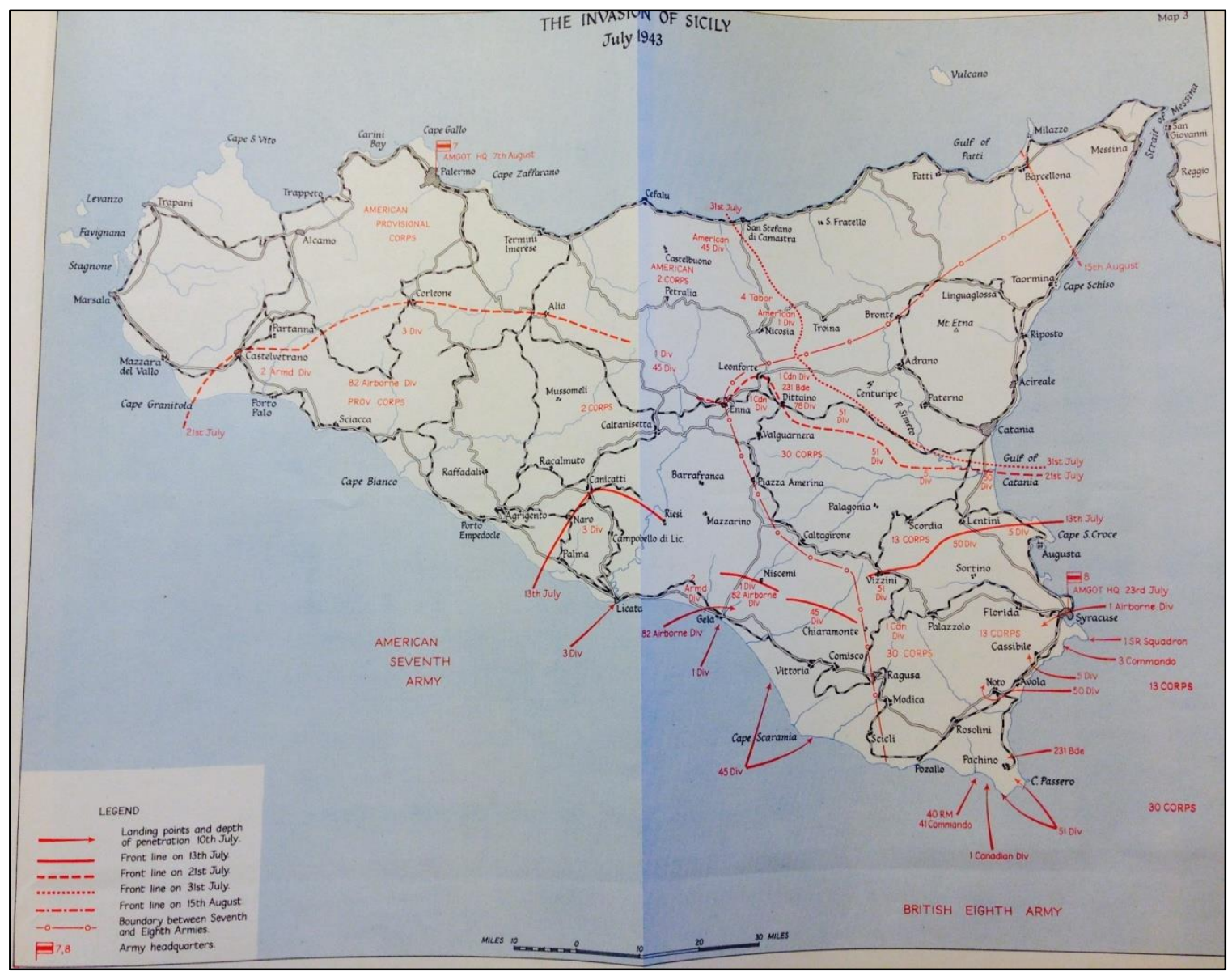

Figure 1. Timeline for Sicily Invasion (Operation Husky), Map 3

Source: Charles R.S. Harris, History of the Second World War, United Kingdom Military Series: Allied Military Administration of Italy (London: Her Majesty's Stationery Office, 1957), 34.

The Allied formations themselves caused the organizational problems with the initial test of AMGOT in Sicily. First, ground force commanders included only minimal portions of CAO personnel during the initial and secondary waves of the assault. As planned during the initial phases, all CAOs fell under the local ground force commander they supported. Knowing the AMGOT Headquarters would not be established for a period after the invasion, some units retained the CAOs in the rear and failed to properly integrate them with ground forces on the move. For instance, CAO teams under Eighth Army, despite landing during the first three days of 
the invasion, did not move forward into the island for almost two weeks..$^{93}$ The lack of integration between the intentions of AMGOT and the Seventh and Eighth Armies leadership greatly dulled the effectiveness of early civil affairs operations. Reciprocally, the mismanagement forced ground commanders to deal with civil affairs problems themselves, with minimal support. ${ }^{94}$ Tactical leaders, leaving their civil affairs specialists on the beach, quickly discovered the mounting civilian crisis too much to handle on their own. Additionally, the role of civil affairs remained unclear throughout all formations, with examples of ground forces acting in ways in polar opposition of AMG efforts. For instance, combat troops interfered and even disarmed members of the carabinieri specially assignment from the local CAO. ${ }^{95}$ The blurred areas between the forward line of troops and rear areas of military government played havoc with command and control of operations across the Sicilian territory. This confusion was not truly a planning failure, but a byproduct of the tempo the ground forces displayed. Much like the AMGOT organization, the tempo and vastness of the captured territory made it difficult for tactical commanders to truly define the areas of responsibility in regards to military governments.

The greatest oversight in the initial execution of AMGOT is the lack of internal transportation assets for CAOs at local and provincial levels. ${ }^{96}$ The vulnerability exposed in the civil services system on Sicily was the lack of transportation among the Italian people from which many AMGOT planners had expected to use. The local movement of food, coal, and materials from the rural to the urban essentially disappeared upon the invasion or was confiscated by the retreating Nazi forces. Undersupported and overwhelmed CAOs begged, borrowed and stole any

\footnotetext{
${ }^{93}$ Komer, ch. 2, 34.

${ }^{94}$ Ibid., 42.

${ }^{95}$ Ibid., 43.

${ }^{96}$ Coles and Weinberg, 197.
} 
transportation asset they could to maintain the essential services for their area. Using initial landing beaches, the relief supplies brought onto the island had to be transported overland to support the impoverished Italian populace. Since the AMGOT organization lacked any internal assets, the lowest levels improvised to best meet the needs of the people with varying levels of success.

As the Allied forces continued the advance into the Italian mainland, the lessons learned for the AMG had partially taken hold. As directed by the MGS in September 1943, AMGOT field commanders generated a consolidated report on their activities and experiences in Sicily, though it was not ready for the planning of Salerno. This report highlighted several key organizational lessons to improve future military government operations on the Italian mainland. The experience demonstrated the need for greater visibility and integration of AMGOT and their CAOs into the combat formations, leading up to the invasion and during the early phases of the assault. Many CAOs felt that they were not properly integrated into the efforts of combat units and often only called forward for emergencies. The commanders' assessments also determined that CAOs "should be present in invaded cities at the time of their capture." ${ }^{.97}$ Having CAOs present as ground forces arrived in a city greatly alleviated the burden on the tactical commanders and allowed AMG to quickly establish direct liaison with city officials. Additionally, the lesson regarding AMGOT transportation stemmed from the innovative actions of CAOs across the provinces. The absence of dedicated and organic transport for AMGOT greatly hindered operations initially, as locally requisitioned traffic was wholly inadequate. The lack of transportation delayed the arrival and distribution of humanitarian foodstuffs, failing to address the immediate requirement for the Italian people. In a Chief Civil Affairs Officer report to the

\footnotetext{
${ }^{97}$ Coles and Weinberg, 198.
} 
MGS on August 5, 1943, an unidentified CAO reiterated the severe deficiency in mobility planning for CAOs,

Experience here [Sicily] emphasized the complete impotence of Civil Affairs Officers without adequate transport landed $1^{\text {st }}$ wave.

Absence of transport occasioned great difficulties for Seventh Army parties, and complaint to be by GOC [General Officer Commanding] Eighth Army for failure of CAO to arrive in time ${ }^{98}$

With no transport, CAOs struggled to properly supervise their assigned areas as the occupied territory continued to increase daily. ${ }^{99}$ Often, the smaller villages went for weeks without CAO involvement or supervision. Although not deliberately neglected, CAOs were just unable to reach them.

The removal of emphasis on immediate defascistization of the Italian administrative system was the pragmatic compromise learned through this initial operations in AMGOT. Allied Forces conducted arrests of prominent Fascist leaders during their march through Sicily. However, local CAOs only removed those parties directly hindering the establishment of AMGOT. ${ }^{100}$ The AMGOT officers and on-ground CAOs understood that it was better to slowly weed out the Fascist supporters than conduct wholesale action and cripple the reconstitution efforts. As illustrated by Lord Francis Rennell, Chief of Civil Affairs,

In practice all legislation in the land remain in force unless it's contrary to humanity or dangerous for the occupying troops. In the case of legislation contrary to the dictates of humanity, powers are taken in a subsequent proclamation either to suspend or abolish or to render inoperative legislation of which the United Nations cannot approve. In Italy that legislation is largely what may be called Fascist legislation.

${ }^{98}$ Chief Civil Affairs Officer Message to FREEDOM for Miltary Government Section, 5 August 1943, Walter Bedell Smith Collection of World War II Documents, box 20, 58, DDEL.

${ }^{99}$ Coles and Weinberg, 198.

${ }^{100}$ Ibid., 195. 
There have been introduced into the Italian penal code and to some extent into the Italian civil code, certain provisions of a Fascist nature which cannot be hacked out or abolished without affecting other articles ${ }^{101}$

Arguably, the greatest success of initial operations was the risk that AMGOT leadership took on empowering the initiative of local CAOs throughout Sicily. Born out of necessity, with small numbers and little transport, brave individual CAOs were assigned to large areas seemingly on their own. Addressed as the big gamble, the success of the individuals contributed immensely to larger success during the initial weeks. ${ }^{102}$ The AMGOT considered the significant safety risk to the CAOs, as leadership feared incidents with stray Italian soldiers, criminal elements or angry mobs. This gamble also included the wise decision to retain the carabinieri as the nucleus of a local police force. ${ }^{103}$ The carabinieri were the national police force for Italy and remained in place following the removal of Fascist control. For a large part, the carabinieri, while disarmed, provided the contacts and legitimacy for the individual CAO, while also filling in for personal security. It was noted, "the carabinieri have taken whatever has been done with dignity and a sense of duty with a long tradition" and loyalty to the Italian people. ${ }^{104}$ Additionally, the strategic direction for CAOs to avoid direct threats towards the legitimacy of the King of Italy, also played a role in garnering support among the loyal population towards AMGOT's objectives. The carabinieri and the Italian military both claimed an oath to the King and not directly to the Fascist governmental system. AMGOT, using this base oath to the monarch, continued to facilitate operations leading to the eventual surrender. The inclusion of a portion of Italian representatives and the maintenance of existing systems greatly fed initial military government efforts, despite its

\footnotetext{
${ }^{101}$ Lord Rennell, "Allied Military Government in Occupied Territory,” International Affairs (Royal Institute of International Affairs 1944-) 20, no. 3 (July 1944): 310, http://www.jstor.org/stable/3018557 (accessed 23 March 2014).

${ }^{102}$ Coles and Weinberg, 195

${ }^{103}$ Ibid., 196.

${ }^{104}$ Ibid.
} 
heavy reliance on Allied Forces for funds and provisions. In the AMGOT assessment on July 30, 1943, General Alexander assessed that the political situation in Sicily was definitely favorable with the removal and arrest of high-ranking Fascists proceeding systematically with no significant dislocation of administrative machine. His assessment of AMGOT on the island was positive leaving General Alexander personally satisfied. ${ }^{105}$

\section{POLITICAL UPHEAVAL WITHIN THE ITALIAN GOVERNMENT}

The outcome of the Casablanca Conference in January 1943 shaped military government operations and the direction GEN Eisenhower hoped to take Italy. The meeting between President Roosevelt and Prime Minister Churchill established the groundwork for Allied efforts towards the defeat of the Axis Powers in Europe. Influencing operations in Italy, the Casablanca Conference provided political limitations in two areas for the Allied planners. The first called for the unconditional surrender of the Axis Powers and "the destruction of the philosophies in those countries which are based on conquest and the subjugation of other people." ${ }^{106}$ These elements demanded the complete surrender of the Italian Government, defeat of the Italian Army, and eradication of Fascism. However, Casablanca also limited available military resources where the preponderance directed towards a cross-channel attack. While the British gained American support for the Sicilian invasion and potential follow-on operations in Italy, the British were also forced to agree to the May 1944 execution of Overlord. ${ }^{107}$ Additionally, building on Casablanca, the Quebec Conference in August 1943, reaffirmed British commitment to Overlord and the unquestionable agreement that "it should have absolute priority over Mediterranean

${ }^{105}$ MGS Report from AMGOT to FREEDOM, submitted by Combined Civil Affairs Committee for General Alexander, 29 July, 1943, report dated 30 July 1943, Walter Bedell Smith Collection, box 20, 349, DDEL.

${ }^{106}$ Office of the Historian, “The Casablanca Conference, 1943," US Department of State, http://history.state.gov/milestones/1937-1945/casablanca (accessed 14 February 2014).

${ }^{107}$ Sainsbury, 34. 
operations." ${ }^{108}$ The commitment to Overlord also emplaced the stipulations to return divisional forces and landing craft from the Mediterranean in November 1943, effectively making the pending Italian campaign an economy of force. ${ }^{109}$ GEN Eisenhower would have to continue the Italian campaign with the forces already allotted and with the understanding that the Mediterranean would never be the Allies' decisive effort.

The Allies conducted military government operations, largely in line with these political intentions, including economy of force, remove Fascism, establish stable governance, but the rapidly evolving political situation within Italy called for adaptation not expected during the initial planning. The only feasible solution for AFHQ and its Military Government Section was to shape operations in Sicily/Italy to produce the surrender, under such conditions that would still leave a co-operative central government. ${ }^{110}$ The element of a co-operative government had direct and lasting implications toward the mission of the AMG as it provided the possibility of alleviation of governance in rear areas. ${ }^{111}$ Understanding that AMG was completely inadequate to administer to the entirety of Italy, the call for a co-operative government allowed the transfer of administrative control in areas far from the front of combat operations. In the minds of Military Government Section planners, transfer to an Italian co-operative authority alleviated much of the strain on resources and personnel within the Seventh and Eighth Armies. This effort was even more critical as the Allied Forces pushed towards the Italian mainland, after successfully routing Italian/German formations on Sicily.

${ }^{108}$ Sainsbury, 35 .

${ }^{109}$ Ibid.

${ }^{110}$ Coles and Weinberg, 218.

${ }^{111}$ The term AMGOT was changed to AMG due to cultural sensitivities as Italians were beginning to be seen as potential partner's against Nazi forces on the Italian mainland. 
The dramatic fall of Mussolini on July 25, 1943, laid the groundwork for what many planners saw as a key element towards a co-operative government, the removal of the Fascist figurehead. In military message on the situation from COL McClure, Propagdanda Warfare Branch, the interpretation of the Italian proclamations of Mussolini's removal was shared with the shocked Allied military organization:

The proclamations of both the King [Victor Emmanuel III] and Badoglio [Mussolini's military replacement as head of the Italian Government] appeal to the populace to rally round the monarchy and betray uneasiness on the question of public disorder. The King's declaration that "No recrimination can be tolerated" also suggests fears that Anti-fascists will try to take immediate revenge, while Badoglio warns fascists and Anti-fascists that order will be maintained with utmost energy. ${ }^{112}$

However, many questions remained unanswered for AMG planners regarding the next phase of operations. With Benito Mussolini divested of power and the King Victor Emmanuel III resuming control of his realm and command of the Italian Armed Forces, all planning assumptions were drastically altered. ${ }^{113}$ Would Italy resist an invasion of the mainland? Would Italy succumb to the call for unconditional surrender called for by Allied political leaders? How would German Forces within Italy react to a potential Italian surrender? Lastly, how can Allied Forces avoid the utter collapse of the Italian Government and avoid further entanglement of forces on the peninsula? All these questions had deep impacts on the execution of AMG operations following the invasion of mainland by Allied Forces. More directly for the AMG, the determination of "the most desirable type of control would be military government, control of an Italian Government by an armistice commission, or a combination of both systems."114

\footnotetext{
${ }^{112}$ Message to COL McClure for COL Hazeltine, Propaganda Warfare Branch (PWB). Italian Home Propaganda Summary Week ending 25 July, 1943, 28 July, 1943, Papers of Edward Lilly, box 39, 324, DDEL.

${ }^{113}$ Murphy, 186.

${ }^{114}$ Komer, ch. 3, 2.
} 
Frustrated with the political limitations to enforce the call of unconditional surrender, in a message to the CCS, GEN Eisenhower asked for more flexibility in the handling and negotiating with the Italian government. In this message on June 19, 1943, GEN Eisenhower highlighted the two standing objectives for a post-Sicily Italy operation: “(A) The military objective of eliminating Italy from the war, i.e., destroying and rendering ineffective the Italian land, sea and air forces wherever they may be; (B) the political objective of delivering the Italian people from the Fascist regime which led them into war and of restoring Italy as a free nation."115

With military intent of conducting operations to occupy the peninsula to include Rome, the severity of potential Italian resistance remained unclear. To help alleviate this resistance, GEN Eisenhower requested the authority to negotiate with "military or civilian groups or with members of the Royal family" to quickly assess and execute the evolving situation to support military necessity. ${ }^{116}$ The CCS denied this request, stating that in the eyes of the political leadership (President Roosevelt and Prime Minister Churchill), GEN Eisenhower should "be limited to concluding local surrenders" and not "fix on general terms of surrender or armistice without the approval of both governments." 117 This direct separation of military action and the political capitulation greatly limited CinC's ability to set conditions for peace and governance within occupied areas. ${ }^{118}$ Reiterated by Mr. Murphy, the political attaché for Roosevelt, and Mr. Macmillan, the political representative for Churchill, that despite the seemingly godsend of an opportunity in the Italian upheaval, AFHQ lacked the authority to initiate such political

\footnotetext{
${ }^{115}$ Coles and Weinberg, 223.

${ }^{116}$ Ibid.

${ }^{117}$ Ibid., 224.

${ }^{118}$ The decision to limit GEN Eisenhower is linked to the unfolding of the Darlan Deal in North Africa and its political fallout, even though GEN Eisenhower was absolved of the blame. Kenneth Davis, Experience of War, The United States in World War II (New York: Doubleday and Company, 1965), 427.
} 
maneuvers. ${ }^{119}$ Looking back, the inability to quickly use the departure of Mussolini and the failure to negotiate more favorable political terms with the Italians was a missed opportunity. However, gaining an earlier surrender would have created a governance system that relied more heavily on AMG, while still turning aggression against an occupying German force.

To fill the vacuum created by Mussolini's departure, King Victor Emmanuel appointed Marshall Badoglio as the Prime Minister of the new Italian government, in an effort to distance itself from Fascist influence and control. A Joint Intelligence Assessment on the fall of Mussolini, dated July 27, 1943, addressed the full significance of this change in power. The AFHQ assessment of the nature of the new Italian government was supportive the report divulged the following evaluation:

Badoglio has been appointed head of the Government in Italy. Has always been antiFascist and anti-German. Is therefore not man who would be chosen to lead last defence of Fascist Italy as ally of Nazi Germany. Thus establishment of Government under Badoglio involves more than mere change of Cabinet. It involves change of regime which not be carried out without great shock to Italy's war effort. ${ }^{120}$

While the convoluted actions of the Badoglio government echoed its concept for the preservation of Italy, the formal surrender negotiations began on August 31, 1943. Many military planners and Italians alike distrusted Badoglio from the very beginning. Although assessed as an anti-Fascist, Badoglio had remained an active member of the Fascist party since 1936 and personally led Italian forces against Ethiopians and Republican Spain. Like Darlan, Badoglio was an intriguer and opportunist who at that very moment was engaged in trickery and double-dealing between Allied Forces and the remaining German elements. ${ }^{121}$ However, Badoglio was the only option available and the Allied political leadership committed to Badoglio, or at least to the

\footnotetext{
${ }^{119}$ Murphy, 186.

${ }^{120}$ Message to AFHQ Algiers G2 FREEDOM for Joint Intelligence Committee from Joint Intelligence, 29 July, 1943, Eisenhower Pre-Presidential Papers, ser. 3, box 12, 340, DDEL.

${ }^{121}$ Davis, 428.
} 
position he held. General Alexander, the British Military Governor in Sicily, eloquently described the precarious position of the Allied and Italian Forces to the American and British political advisors. He stated that the Germans already had almost nineteen divisions in Italy, many of which escaped from Sicily the previous month, and the Italians had sixteen divisions, with unconfirmed loyalty to the King or Germany. ${ }^{122}$ Up to this point, the Allies had only a handful of divisions, and in order to continue the fight for Italy, Italian cooperation must be quickly obtained to meet the Allied objectives. According to Mr. Murphy, General Alexander declared his willingness to risk his reputation and, if necessary, retire from the Army, should his government disapprove his insistence on immediate signature by the Italians and acceptance of Italian cooperation against Nazi Forces within the peninsula. ${ }^{123}$ In order to support military necessity, the addition of the Italian divisions had to be quickly turned against their former partners and brought in line with Allied armies. Again, the political direction of the Allied Forces challenged the success of the military preferences in the Mediterranean theater.

The new political situation within Italy, created by the Armistice and eventual cobelligerency, altered the operational concept for AMGOT in Italy. ${ }^{124}$ The shift caused by the upheaval forced the complete overhaul of the conduct of further military government operations. Allied Forces found themselves in a situation where the operational approach applied to Sicily was unable to be brought forward due to political restraints and limited civil affairs resources. However, military government was still the only feasible option for combat areas. The dual nature of governance required for Italy, slowly and fitfully developed by the AMG organization, often came at the expense of efficiency. The nature of the operational environment created a need for a

\footnotetext{
${ }^{122}$ Murphy, 190.

${ }^{123}$ Ibid.

${ }^{124}$ US Army, Review of Allied Military Government and of the Allied Commission in Italy, 13.
} 
competing command and control structure between the tactical commanders of the Allied Armies and one solely dedicated to AMG. Additionally, the strategic nature of the political dealings even further directly incorporated AFHQ and MGS into the execution of AMG on the Italian mainland.

The formal recognition of the Marshal Badoglio Government, followed by the conferment of Italy's status of co-belligerent against Nazi Germany, fundamentally changed the nature of military governance to Italy. Coming to a head on September 8, 1943, four critical events occurred on the same day, drastically altering Allied AMG operations in Italy. Allied Forces conducted an amphibious assault at Salerno. German forces seized Rome, the center of political power in Italy. GEN Eisenhower publically announced the terms of the Armistice between the Allies and Italy. Lastly, King Victor Emmanuel III was forced to flee from Rome, never to return as King. ${ }^{125}$ Possibly the most crucial time for the future of Italy, was the dramatic swing of allegiance of the King away from Germany, all while knowing that he had committed Rome, his country, and people to the horrors of hostile German occupation. The combination of these four events all wrote the underlying plot points in the narrative of governance within Italy. All four aspects of the political shift weighed on the decisions and actions of the Allied Forces for the remainder of the campaign.

While the initial Armistice terms did not call or expect Italy to actively fight against Germany, Prime Minister Churchill quickly began planning and maneuvering for Italy’s conversion as a full co-belligerent. ${ }^{126}$ The shocking announcement of the Armistice also generated confusion within the Italian Forces and government, many of which were hoping this truly meant the end to war. Slipping away in the early evening hours just before the announcement of the Armistice, King Victor Emmanuel III and Marshal Badoglio travelled

\footnotetext{
${ }^{125}$ Murphy, 196.

${ }^{126}$ Ellwood, 41.
} 
anonymously to Brindisi. The King even left behind all his belongings in order to avoid raising suspicion with the German and Italian officials. ${ }^{127}$ Notably the majority of the King's government remained in Rome, either by choice or by ignorance of the situation. The decision to leave the highest level of administration in the capital eventually haunted AMG operations as the technical experts, career politicians, and administrative heads all remained locked behind enemy lines.

Italian Forces within and around the city, never directed to engage the Germans, put up virtually no resistance, as Nazi forces quickly seized Rome unopposed. ${ }^{128}$ Declining morale, scarcity of resources and material, and the lack of strategic direction all forced the capitulation of the Italian Army and the reason why the half-million troops in Northern Italy and occupied France "seemingly vanished into thin air." ${ }^{129}$ The Italian Army's capitulation in Rome set the stage for a deliberate delaying operation of defensive lines by German forces that would cost the Allies dearly.

Co-belligerency is another example of political intentions driving military application, Prime Minister Churchill's bias towards saving the monarchy drove the conversion. The Prime Minister wrote in Closing the Ring, "I was sure that King Emmanuel and Badoglio would be able to do more for what had now become the common cause than any Italian Government formed from the exiles or opponents of the Fascist regime." ${ }^{130}$ After convincing President Roosevelt, the Allies adopted this policy for military governance in Italy with its long-lasting implications. The Churchill-Roosevelt directive for GEN Eisenhower, established the root guidance for cobelligerency on September 23, 1943. The Allied Forces were to "permit the Italian Government to

${ }^{127}$ Murphy, 196.

${ }^{128}$ Ibid.

${ }^{129}$ Albert Garland and Howard Symth, The Mediterranean Theater of Operations, Sicily and the Surrender of Italy (Washington, DC: Center of Military History, 1993), 533.

${ }^{130}$ Ellwood, 41. 
assume the status of a trusted co-belligerent in the war against Germany if that government declared war on Germany and if it promised to give the people the right to decide the form of government they wished, though not before the Germans were evicted from Italian territory."131 However, this assessment co-centered on fundamental assumption that the Italians could retain control of their own country. ${ }^{132}$ The abandonment of the central administration in Rome, the appointment of Badoglio and a growing anti-Fascist movement, all threatened the Italians' ability to effectively govern.

The constitution of a friendly Italian government removed the requirement for an AMG infrastructure, especially in areas to the rear. Additionally, this directive planted the seeds for political change within the Italian system that eventually led to abdication of the King.

Acceptance of the Armistice and enforcement of the directive guided the working agreement with the recognized Italian authority and the AMG. Accepted by Marshal Badoglio, the accord stated that AMG continue as before in the occupied provinces. However in the provinces of Taranto, Bari, Brindisi and Lecce the government remained in the hands of the King and the Marshal, subject only to such control under the armistice terms as might be imposed by military necessity. ${ }^{133}$ In the four isolated provinces, AMG proclamations were not declared, but AMG personnel were installed in the local administrative offices as liaison officers. Designed at the preliminary stage of policy, AMG adopted these interim arrangements, focusing its efforts in a narrow band of territory behind the Allied armies, progressively handing back territory in the rear

\footnotetext{
${ }^{131}$ Coles and Weinberg, 445.

${ }^{132}$ Murphy, 191.

${ }^{133}$ Harris, 74.
} 
to the Italian government, as Allied forces advanced toward Rome. ${ }^{134}$ In a message from BG Holmes, head of the MGS at AFHQ, stated:

Instead of establishing military government, we [General Rennell, CCAO, and General Holmes] agreed to allow the Marshal [Badoglio] to govern these four provinces with A.M.G. officers established in prefectures and other appropriate places as liaison officers, but with the distinct understanding that they were to exercise substantial influence on the local administration. ${ }^{135}$

Even at this stage of operations, GEN Rennell and GEN Holmes recognized the need for a timely transfer of stabilized areas to legitimate Italian authority to alleviate requirements for the AMG. In a message from Lord Rennell to the MGS, AFHQ on September 24, 1943, he suggested the "division of responsibilities to limit mobile AMGOT to combat areas and segregate static areas to another organization." ${ }^{136}$ Further, "Areas cleared and settled would in the circumstances be turned over to the Italians, subject to the control we would exercise through the Allied Commission. That we install military government only where it is necessary for military operations and that, as soon as conditions permit, we hand the territory to appropriate civil authorities." 137 The qualified personnel shortages forced this arrangement within the CAOs and more importantly the alleviation of the requirement for Fifth and Eighth Armies to support operations far behind the front line trace. A message from BG Holmes in late September 1943 highlighted the personnel shortages facing AMG. BG Holmes reported, "The thinning out process, moving personnel from rear areas to forward areas, cannot proceed as rapidly as originally anticipated due to the inability of the Italian Government to resume effective control under present and prospective

\footnotetext{
${ }^{134}$ Harris, 74.
}

${ }^{135}$ Message from BG Holmes to AFHQ, 28 September 1943, Eisenhower Pre-Presidential Papers, ser. 3, box 12, DDEL.

\footnotetext{
${ }^{136}$ Coles and Weinberg, 252.

${ }^{137}$ Harris, 74.
} 
conditions." 138 The great confusion established Italy as a co-belligerent, creating a massive administrative backlash for which the Allies were largely unprepared. The North Africa administrators compared to their Italian counterparts were vastly more organized and functional. ${ }^{139}$ The rapid relinquishment to capable Italian authorities was not feasible and dramatically slowed the move of CAOs from rear areas to the front lines. The dependency and inadequacy of the interim Italian Administration was too ingrained for independent action.

Additionally, the military campaign in Italy became far more devastating and destructive, as German Forces essentially punished the Italian people for their treason and support to the Allied Forces. A cable from GEN Marshall, CCS, to GEN Eisenhower on October 10, 1943, lays out the narrative surrounding the transition of Italy to a co-belligerent. It also highlights the tension between the Armistice (short terms) and the Instrument of Surrender (long terms) in the eyes of the United Nations.

The Governments of Great Britain, the United States and the Soviet Union acknowledge the position of the Royal Italian Government as stated by Marshal Badoglio and accept the active cooperation of the Italian nation and armed forces as a co-belligerent in the War against Germany. The military events since September $8^{\text {th }}$ and the brutal treatment by the Germans of the Italian population, culminating in the Italian Declaration of War against Germany have in fact made Italy a co-belligerent and the American, British and Soviet Governments will continue to work with the Italian Government on that basis. The 3 Governments acknowledge the Italian Government's pledge to submit to the will of the Italian people after the Germans have been driven from Italy, and it is understood that nothing can detract from the absolute and untrammelled right of the people of Italy by constitutional means to decide on the democratic form of Government they will eventually have.

The relationship of co-belligerency between the Government of Italy and the United Nations' Governments cannot of itself affect the terms recently signed, which retain their full force and can only be adjusted by agreement between the Allied Governments in the

\footnotetext{
${ }^{138}$ Coles and Weinberg, 240.

${ }^{139}$ Murphy, 207.
} 
light of the assistance which the Italian Government may be able to afford to the United Nations' cause. ${ }^{140}$

The political intentions and motivations of Washington, London, and Moscow, affected the execution of military governance and the transition to Italian authority, partially based on the Italians' ability to support the war effort. The establishment of first the Armistice Control Commission and later the Allied Control Commission served as the cornerstone of the political agenda in Italy. Politically entwined with the conditions of the Armistice forced upon the weak Badoglio Government, the Commissions served as the international [political] authority over Italy as a co-belligerent. The Armistice Control Commission, as the name entails, ensured the enforcement of the both the military short terms, also known as the instrument of Armistice that was accepted by Badoglio on September 3, 1943. The political long terms, also known as the Instrument of Surrender, accepted on September 29, 1943, reinforced the articles of the Armistice and confirmed Italian subjugation to the Allied military necessity. The Allied Control Commission formed under Article 37 of the long terms, regulated and executed the instrument of surrender under the orders and general direction of the CINC. ${ }^{141}$ Additionally, the functions of the Control Commission, as directed by internal directives on September 6, 1943, were to "first, enforce and execute the instrument of surrender, and secondly, to ensure the conduct of the Italian Government conformed to the requirements of the Allied base of operations. It was also to be the organ through which the policy of the United Nations towards the Italian Government would be conducted." 142 The integral role of the CAO in the Commission's execution and enforcement

\footnotetext{
${ }^{140}$ Telegraph Cable from General Marshall to General Eisenhower, ref. no. 9765, 10 October, 1943, Eisenhower Pre-Presidential Papers, box 1, DDEL.

${ }^{141}$ The Avalon Project, Armistice with Italy; Instrument of Surrender; September 29, 1943, Lillian Goldman Law Library, Yale Law School, http://avalon.law.yale.edu/wwii/italy03.asp\#art37 (accessed 23 March 2014).

${ }^{142}$ Harris, 108.
} 
became a prime aspect for AMG operations going forward. From its creation, the integration of the Control Commission intended to include the AMG operations and structure, however the actual integration of the two organizations was more difficult to execute than expected.

The dramatic reorganization of the Badoglio Government and the decentralization of the AMG between the Italian mainland and Sicily spurred the transition from Armistice Control to Allied Control Commission. Most notably, the establishment of the Control Commission greatly expanded the MGS at AFHQ, essentially growing the MGS into a full sized G section.

Ultimately, the MGS was elevated to the general staff section known as G-5, in May 1944 by GEN Sir Henry Wilson, GEN Eisenhower's replacement. Regardless of the administrative network established around the Control Commission, its essential purpose was to be the conduit for advising the Supreme Commander in his task of administering policy of the United Nations towards Italy. ${ }^{143}$

The mission of the Allied Commission [Control was removed after a short time] was based along five lines.

First, to organize and coordinate military government operations with the Fifth and Eighth Armies in direct support of combat troops; second, to render aid 'as practicable' to the civilian population in the rear of the armies in order to allay disease and unrest; third, to prepare the governmental administration and economy to be turned back to the Italians as quickly as possible; fourth, to supervise execution of the terms of the Italian Armistice; and fifth, to be the spokesman of the United Nations to the Italian Government. ${ }^{144}$

Concurrently, the transition of AMG to operate solely in areas directly involved in combat operations required definitive guidelines for transition of territory to Italian control. However, in execution, the establishment of Military Districts against a fluctuating AMG command structure greatly complicated operations in the interim. For instance, Sicily was declared No. 1 Military

\footnotetext{
${ }^{143}$ Harris, 116.

${ }^{144}$ US Army, Review of Allied Military Government and of the Allied Commission in Italy, 5.
} 
District, in September 1943, but by October had been split into a second Military District. ${ }^{145}$ These districts embraced the four provinces of King's Italy with all administration handled by the Badoglio Government, under the auspices of the Allied Control Commission. Not surprisingly, the British Eighth Army occupied this area. However, the territorial division of AMG created a leadership vacuum that hindered the speedy transition of rear areas to Badoglio. The ineptitude of the Badoglio Government to assume responsibility of new territory called into question the Allied support. It was Prime Minister Churchill, who continued to urge support to Badgalio and the monarchy as an element of stability. The Prime Minister argued that there were few experienced liberal politicians in Italy after two decades of fascism; therefore, it was necessary to work with and support right-wing figures such as Badoglio. ${ }^{146}$ General Alexander and Lord Rennell, moved their headquarters to Bari following the invasion of the Italian peninsula. The headquarters staff of AMG remained in Palermo, and most importantly, the lead on negotiations with the King and Badoglio were handled by AFHQ at Brindisi. Additionally, the planning efforts for military governance within the MGS centered from Algiers under AFHQ removed by distance from actual operations. The logistical and communications challenges, with the dispersal of command and control, produced a disjointed and unsynchronized application of military governance and civil affairs for an extended period. The underlying logic for a dispersed command and control structure was based on the political perception from within Italian people. According to Lord Rennell, the inclusion of Sicily under the same AMG umbrella as the Italian mainland contributed to the mitigation of separatist movements and a growing anti-Fascist element in Italy. ${ }^{147}$ Opponents of the weak Badoglio Government sought to undermine its attempt to restore order

\footnotetext{
${ }^{145}$ Harris, 95.

${ }^{146}$ Smith, 68.

${ }^{147}$ Ibid., 96.
} 
within the Military Districts and establish a system favorable to their own terms. Despite military governance laws against political activity within Italy, a viable separatist and communist political movement threatened the Italian Administration from within the rear areas.

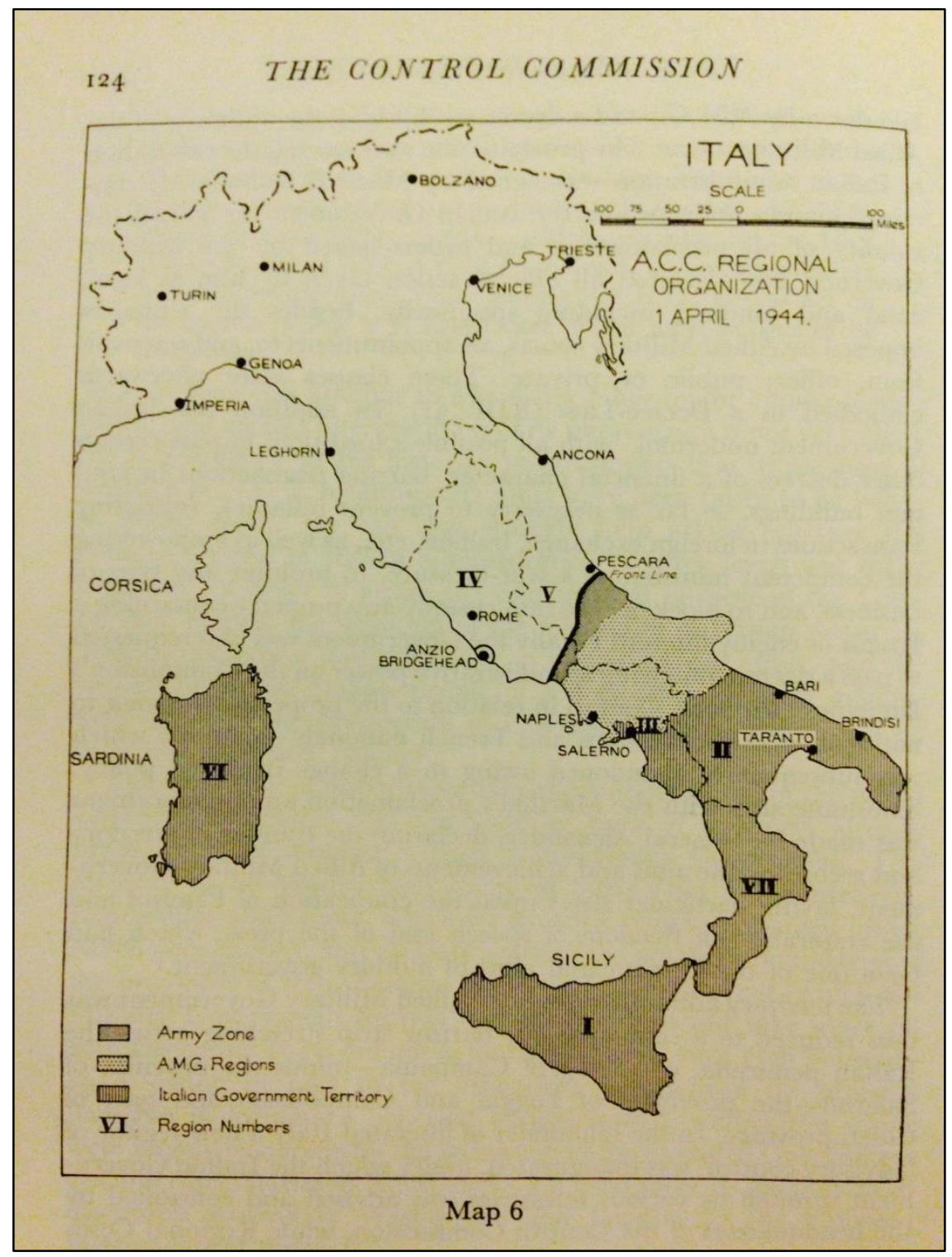

Figure 2. Allied Control Commission Regional Organizations as of 1 April 1944

Source: Charles R.S. Harris, History of the Second World War, United Kingdom Military Series: Allied Military Administration of Italy (London: Her Majesty's Stationery Office, 1957), 124. 
Ultimately, the headquarters situation was resolved on October 24, 1943, when GEN Eisenhower authorized the formal division of AMG in the Mediterranean. First, AMG Rear consisted of headquarters elements in Palermo, who administered the two Military Districts within Sicily proper. They continued to support and administer these districts and facilitate the transition of administration of the Badoglio Government. Second, AMG Forward consisted of three commands, comprised of civil affairs forces of Fifth Army and Eighth Army and the AMG Fifteenth Army Group. Leading elements of AMG's Fifth and Eighth Armies spearheaded military governance as divisional forces pushed north on the Italian peninsula. Learning from the challenges during the initial invasion, Fifth and Eighth Armies specifically restructured their AMG organization to produce "mobile formations with their own transport, consisting of 'general purpose' officers with a sprinkling of 'specialists' such as Finance, Public Health, Supply and Legal Officers." ${ }^{148}$ This structure was vastly better integrated into the combat formations and overall formed a more responsive and effective element along the frontlines. AMG Fifteenth Army Group, directly commanded by Lord Rennell, administered and supported AMG Fifth and Eighth, as well as provided military governance to areas following the combat formations, specifically associated with Army's rear boundary. However, basing the division of territory on the existing provincial boundaries of the existing Italian Administration structure was unfeasible. Therefore, it was necessary to group provinces around some intermediate center, thus creating a form of regional decentralization in areas known as compartimento (compartments). AMG was decentralized into a number of Regions, to be activated as Allied armies advanced up the peninsula. Each region administered to one or two of the compartimenti. ${ }^{149}$ According to initial planning efforts by MGS, the regional framework to be extended to the peninsula would be

\footnotetext{
${ }^{148}$ Smith, 96.

${ }^{149}$ Harris, 67.
} 
assigned as follows: (I) Sicily; (II) Calabria; Luciania and Apulia; (III) Campania; (IV) AbruzziLazio; (V) Marche-Umbria; (VI) Sardinia; (VII) Rome-Central Government; and later added were (VIII) Tuscany and (IX) Emilia. As early as July, General Eisenhower authorized planning efforts for decentralized AMG operations as far as Rome, covering regions II, III, IV and VII.

The decentralization of regional commands and separate AMG Headquarters, while considered an administrative necessity, led to considerable complications and inefficiencies in execution. Specifically the application of logistics to AMG Forward and AMG Rear exacerbated the food crisis, the greatest civil affairs challenge in the occupation of Italy. While the organization for the AMG appeared to make sense in application, Allied Forces made no significant change to the logistical channels supporting the new organization. Fifteenth Army Group, responsible for the support of the frontline troops, possessed no internal quartermaster machinery to high headquarters. ${ }^{150}$ An element from AFHQ, known as FLAMBO (its convenient telegraphic moniker), was established in Naples upon its capture in early October 1943.

FLAMBO, commanded by British MG Sir Brian Robertson, was responsible for calling forward shipping to the mainland ports for supplies for all troops on the Italian mainland, as well as civilian supplies. ${ }^{151}$ However, the integration of FLAMBO to sustain AMG failed to alleviate that procurement of supplies, initiated solely in G-4, AFHQ. For instance, AFHQ initiated all supplies requests for Civil Affairs teams on the Italian mainland but abstained from requests for Sicily. FLAMBO pushed all supplies to Italy, but FLAMBO was not responsible for distribution upon arrival. ${ }^{152}$ AMG pulled supplies forward to the front line, with its limited internal transportation.

\footnotetext{
${ }^{150}$ Harris, 97.

${ }^{151}$ Ibid.

${ }^{152}$ Ibid., 98.
} 
To add further complexity, the division of headquarters removed the responsibility of FLAMBO to support Region I for AMG Rear on Sicily, but remained responsible for Region II, administered by AMG Rear. In order to meet the requirements for civilian supplies in Region II, Lord Rennell and AMG Fifteenth Army Group assumed responsibility for the sustainment needs for Region II, despite it no longer being under his command. ${ }^{153}$ Fortunately, in lieu of the complicated service and command structure for the decentralized AMG, dedicated and competent liaisons and planners reinforced the FLAMBO/15th AMG Army Group relationship and operations were executed somewhat smoothly. The convoluted administrative system did not necessarily ease the Italian shortage of food supplies in the winter months of 1943 but also was not responsible either. The root cause was the failure of AFHQ to requisition and release civilian foodstuffs months earlier. ${ }^{154}$

\section{KEEPING YOUR HEAD ABOVE THE WATER}

The challenges for CAOs continued to mount in the field across Italy. German demolitions and sabotage against the Italian administrative infrastructure worsened the civil situation and requirement for direct influence from AMG personnel throughout occupied areas. Looted banks looted, seized food caches, damaged water and sewage systems, and demolished ports; all spurred more strain for field officers. For instance, Allied Forces found the city of Naples nearing complete squalor, when seized by Fifth Army on October 1, 1943. Food was short, and the Germans had damaged the city's sewage and water system, raising concerns for the spread of disease. Abandoning German Forces essentially dismantled any form of administrative system (utilities, post offices, hotels, etc.) through direct actions or coerced Italian desertion. ${ }^{155}$

\footnotetext{
${ }^{153}$ Harris, 8.

${ }^{154}$ Ibid.

${ }^{155}$ US Army, Review of Allied Military Government and of the Allied Commission in Italy, 19.
} 
The execution of military governance by the local CAOs continually fluctuated from city to city and region to region, with all actions interdependent with the moves of the higher government. However, from within the instability rose general guidelines of necessary duties to be tackled. One of the aspects required immediately was labor procurement in occupied areas. As seen in Salerno, Naples required CAOs to organize the recruiting of supply labor for the troops to facilitate offloading supply trains. ${ }^{156}$ Additionally, CAOs directly managed refugees in order to alleviate the burden on the military commander and avoid negative impacts to operations. The refugee problem was reaching critical proportions upon arrival of Allied Forces in Naples forcing immediate action by the CAOs. The Eighth Army AMG report for November 1943, recorded a significant increase of 100 to 550 refugees per day for the entire month, with CAOs collecting nearly 30,000 refugees into the area. ${ }^{157}$

Supplementary to the management of refugees, CAOs also faced the disparity of civilian relief operations. Specifically in Naples, German Forces destroyed the city's infrastructure (aqueducts, sewers, power grids, etc.) as they retreated northward. Food stores and banks were emptied, and hoarding was a continual problem for AMG personnel. Malnutrition and hunger was rampant as the population of the city swelled with refugees, but the arrival of aid was slow. ${ }^{158}$ CAOs managed the administrative system for rationing which improved the general situation over time. CAOs also maintained public safety and order, which included multiple of tasks ranging from law enforcement in accordance with AMG proclamations to clearing the area of unexploded ordinances. A notable element of public safety and triumph of the AMG Administration was its response to the typhus outbreak in Naples in the fall of 1943. The overcrowding in tenements and

\footnotetext{
${ }^{156}$ Daugherty and Andrews, 253.

${ }^{157}$ US Army, Review of Allied Military Government and of the Allied Commission in Italy, 19.

${ }^{158}$ Daugherty and Andrews, 254.
} 
air-raid shelters provided the perfect breeding ground for typhus-carrying lice. In addition, Naples being a key port was crammed with military. Beginning in November, over three million dusting treatments were administered from multiple centers in and around the city, under the authority of the local AMG. During the month of December, reported cases of typhus rose dramatically from 50 persons infected to 300 ; however, due to the aggressive delousing program of the AMG, for the next two months only 10 additional cases were reported. ${ }^{159}$ Ultimately, the effectiveness of the $\mathrm{CAO}$ within Naples mitigated the pending crisis, averting disaster not only for the Neapolitans but for the Allied Armies as well. BG Parkinson, Director of the Public Health Subcommission, noted in his report that the actions in Naples would "stand out as a mile-stone in the field of public health and disease control because here it was the first time that a major epidemic of this vicious disease was not merely curbed but actually brought under control by the vigorous application of delousing measures." ${ }^{160}$ Lastly, a key aspect of the CAOs local responsibilities was tied to the protection of Italy's fine arts and historical artifacts. Ever more important as Allied Forces reached Rome, CAOs established local security patrols to protect, collect, and safeguard key pieces of art and documents. Additionally, CAOs served as liaisons with the Air Forces to avoid the bombing of artistic centers or sites, and prepared a list of "protected monuments" for issue to all formations. ${ }^{161}$

\section{DECENTRALIZATION FAILS, AMALGAMATION WINS}

The analogy of too many chefs in the kitchen is highly applicable to the situation in Italy, in regards to civil affairs and military government. Criticism of the decentralized organization was prevalent, but no more in the comments from Lord Rennell, "The unwieldy size and

${ }^{159}$ US Army, Review of Allied Military Government and of the Allied Commission in Italy, 20.

${ }^{160}$ MGS Report No. 15 from Public Health Subcommision to MGS, 18 April, 1944, Eisenhower Library Collection, ser. 3, box 12 .

${ }^{161}$ US Army, Review of Allied Military Government and of the Allied Commission in Italy, 23. 
constitution of the Allied Control Commission in its present form makes me doubt of its utility at any time, even in Rome." ${ }^{162}$ Continuing current disposition of the Allied Control Commission would almost "guarantee that they [multiple layers of AMG] will interfere in matters which will render any Italian Civil Service machine inoperable." ${ }^{163}$ Multiple organizations, with decentralized headquarters and limited communications in-between, fitfully struggled to raise the Italian Administration through the waning months of 1943, and it was time for a change. The combination of AMG and the Allied Commission (AC) had been long planned, but the actual merger had been postponed by the fluctuating political situation within Italy. However, upon the relocation of the Badoglio Government from Brindisi to Naples in January 1944, GEN Mason MacFarlane, rearranged the staffs and functions of AMG, the AC, and 15th Army Group AMG. ${ }^{164}$ GEN MacFarlane, the Deputy President and Chief Commissioner of the Allied Control Commission and Chief Civil Affairs Officer, was the key individual to revamp the organizational challenges of a separated organization. The unity of command, enabled by the new combined organization, was clumsy initially but provided the flexibility needed for the varying degrees of requirements within Italy. AMG personnel referred to the three spheres of Italian transition, spearhead work with the armies along combat zones; consolidation and collaboration with Italian Administration behind the lines; or purely advisory liaison in "King's Italy." 165 Under the Allied Control Commission/Allied Military Government (ACC/AMG), for truly the first time, the muchneeded proactive nature was addressed by providing focused personnel/skills as the situation demanded. In March 1944, the transfer of Southern Italy and Sicily to legitimate Italian authority

\footnotetext{
${ }^{162}$ Harris, 113.

${ }^{163}$ Ibid.

${ }^{164} \mathrm{US}$ Army, Review of Allied Military Government and of the Allied Commission in Italy, 25.

${ }^{165}$ Ibid., 26.
} 
was announced and was paramount to the successful combination of ACC/AMG. The transfer, long contemplated by military planners, as an earnest of the Allies desire to see the Italian Government assert itself, was also a move calculated to economize manpower. ${ }^{166}$ The personnel strain for ACC/AMG continued to mount as trained, experienced, CAOs and staff called to other theaters. The unification of AMG in both forward and rear areas, under single control, was certainly a vast improvement, and provided for the first time an integrated policy to all of controlled Italy. Surprisingly enough, the ad hoc administrative systems in King's Italy initially created a nightmare of divided controls which impeded efficiency and ballooned unnecessary redundancy. ${ }^{167}$ The formal arrangements with the Badoglio Government established the unity of command between Allied and Italian interests. Any legislation developed by the Italian Government for its own territory was applied by the Control Commission in all regions for which it was responsible, when conditions were considered stable. ${ }^{168}$ Additionally, the AC ensured that any legislation brought forth remained within the guidelines of the Armistice and did not negatively affect ongoing military operations.

${ }^{166}$ US Army, Review of Allied Military Government and of the Allied Commission in Italy, 27.

${ }^{167}$ Harris, 121.

${ }^{168}$ Ibid. 


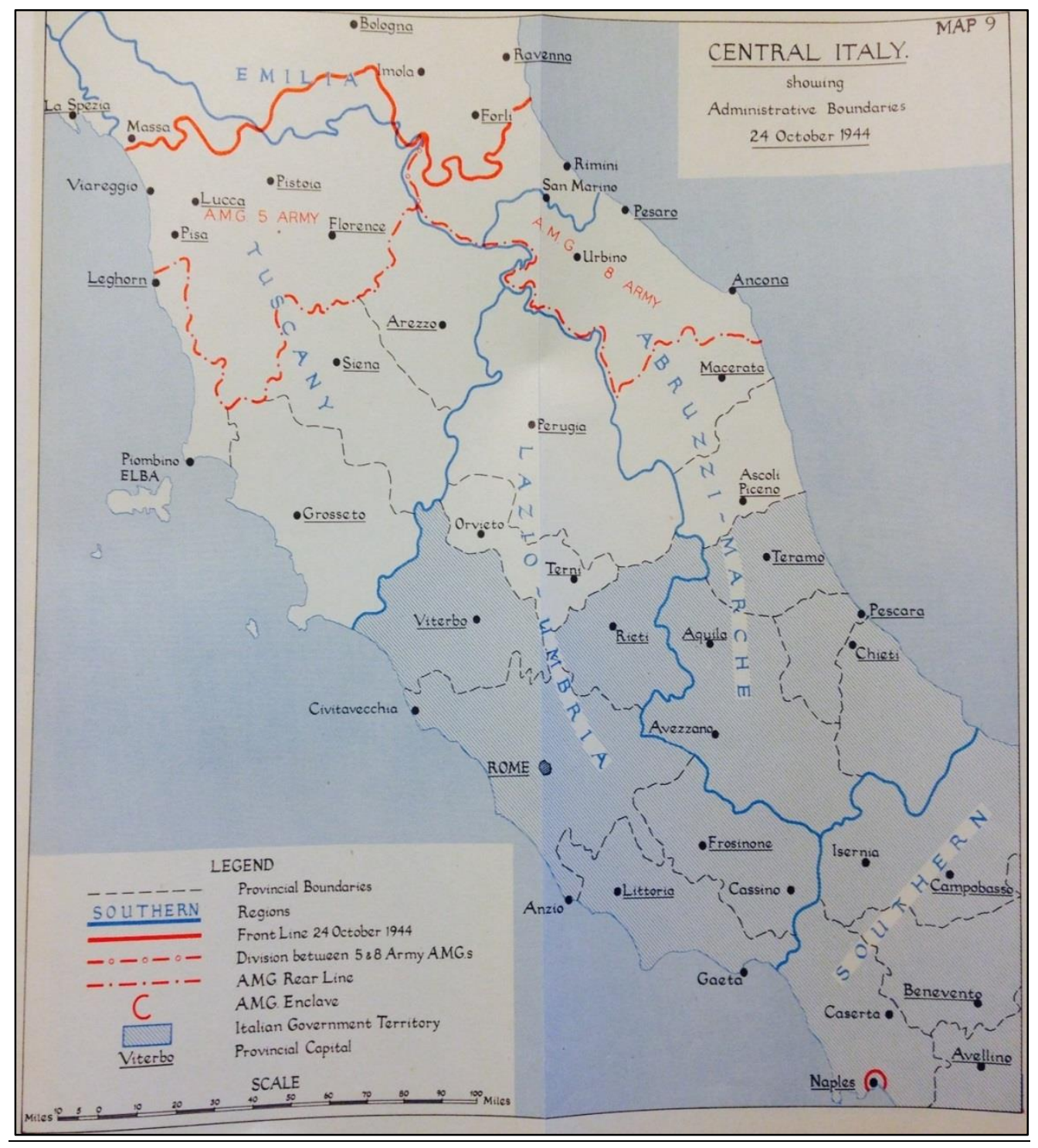

Figure 3. Administrative Boundaries for AMG as of October 1944

Source: Charles R.S. Harris, History of the Second World War, United Kingdom Military Series: Allied Military Administration of Italy (London: Her Majesty's Stationery Office, 1957), 194.

However, the transfer of territory to Italy did not immediately reduce the ACC/AMG presence in the rear areas. The AC maintained its influence and authority ensuring the Italian Administration followed the decrees of the Armistice and defascistization with minimal interference to combat operations. Additionally, the ACC/AMG personnel were intimately 
involved in matters of public safety, of finance, and supply as all these elements were derived from Allied resources. The development of the G-5, from the skeleton of the MGS, also continued to grow during this time. By the middle of 1944, the G-5 was not only overseeing the civil affairs operations in Italy, but also other areas in the Mediterranean (Balkans) and had begun detailed planning for the invasion of southern France. ${ }^{169}$

Gradually, over the remaining months of 1944, and based on the local assessment of Italian proficiency, the numbers of ACC/AMG personnel reduced to a more liaison role. ${ }^{170}$ For instance in Sicily, at the end of January, there were 176 CAOs stationed in various positions at the provincial and local level. At the end of February, that number dropped to 153, with key personnel transferred to newly occupied territory in the North. By the end of March, there only remained 128 CAOs, and by the end of October, only 35 Civil Affair Officers remained, solely in continuing liaison capacity. ${ }^{171}$

\section{POLITICAL CENTER OF NAPLES}

Arguably, the greatest challenge for AMG in regards to the occupation was the tempo surrounding the need for political change from the Italian people. From the earliest of planning stages for military governance, the restriction of political activities of an occupied nation had always been paramount. This concept was immediately shared by both American and British planners and is clearly annotated in the Combined Directive on Military Government In Sicily, May 31, 1943, and Soldier's Handbook. As directed, "The Fascist party will be liquidated immediately and the continuation of any political activity will be absolutely prohibited." 172 The

\footnotetext{
${ }^{169}$ Komer, ch. 7, 26.

${ }^{170}$ US Army, Review of Allied Military Government and of the Allied Commission in Italy, 28.

${ }^{171}$ Komer, ch. 5, 19.

${ }^{172}$ Holborn, 114.
} 
directive also states "neither local personalities nor political groups will be permitted to take part in determining administration (AMG) policies." ${ }^{173}$ AMGOT Proclamations reiterated this sentiment, which every $\mathrm{CAO}$ across the theater presented to the occupied areas and enforced as required. Specifically tied to Proclamation No. 7, Dissolution of Fascist Organizations and Repeal of Laws, Article V, further regulates the right of Italians to hold political meetings and open assemblies. ${ }^{174}$ The Allied intentions behind this effort to limit political activity, directly tied to the forced removal of Fascism from Italy. However, as the operations continued and Italy, formally recognized as a co-belligerent, the $\mathrm{CAO}$ responsibility to prohibit political activity came into question. Naples became the epicenter of the political movement.

Following the Armistice agreement between Badoglio and the Allies, it was determined that upon Allied Forces reaching Rome, political freedom and reorganization of the Italian Government would be most applicable. Politically, Badoglio believed it was in Italy's best interests to withhold political transformation, until a time where the political actors within Rome could successfully be included. While forced by necessity, leaving the political and administrative infrastructure in Rome helped create the political tension for the demand for a new system. In a military message from LTG Taylor to GEN Eisenhower on October 15, 1943, Taylor discusses the Italian sentiment regarding the growing political crisis:

In the course of a conversation with Marshal Badoglio today, he discussed at length his difficulty in forming a satisfactory cabinet. He states that he has a long list of cabinet possibilities drawn from individuals of many political shades who will be available to him upon arrival in Rome. He feels that a stopgap cabinet formed prior to leaving Rome would be useless as it would not have any of the machinery of the government available for performing its functions ${ }^{175}$

\footnotetext{
${ }^{173}$ Holborn, 115.

${ }^{174}$ Harris, 406.

${ }^{175}$ Message from GEN Taylor to GEN Eisenhower, 15 October, 1943, Eisenhower Pre-Presidential Papers, box 1, DDEL.
} 
Badoglio had previously negotiated with the Allied leadership for the postponement of the formation of a full government until the capture of Rome, at which time Badoglio promised to resign. With the reluctant support of the AMG, the interim Badoglio Government attempted to hold on, placing all hopes in the rapid movement of Allied Forces towards Rome.

Before October 1943, the United States, Great Britain, and the Soviet Union had not officially agreed on any definitive goals for peace in Europe or joint arrangements for the posthostilities period in Italy or elsewhere. ${ }^{176}$ The politically accepted definition between the three nations of post-hostilities described the time between the end of hostilities and the conclusion of peace treaties. Forced to use the general clauses within the Armistice and Instrument of Surrender for Italy, AMG developed its practical political, economic, and financial policies with the Badoglio Government by trial and error methods, as the latter retained its focus on Rome. ${ }^{177}$

However, as combat operations slowed and the advance of Allied Forces through the peninsula waned, the political stalemate soured. In a message from the Senior Civil Affairs Officer, LTC Peter Rodd to AMGOT Headquarters, on October 5, 1943, he describes his assessment of the political situation from Sicily:

The doubts and hesitations which exercise the bureaucracy of the island have been very much increased by the Armistice and the events which followed it ... They [the Italian people] have become, at least for the time being, not occupied Italian nationals, but the subjects of AMGOT. The strange and transient nightmare has become an apocalyptic nightmare.

There is ... among the people generally a growing sense of disappointment that first the occupation and later the Armistice has not brought about the Golden Age, and a relief from the restrictions in their personal liberty and the freedom of markets. ${ }^{178}$

\footnotetext{
${ }^{176}$ Holborn, 16.

${ }^{177}$ Ibid.

${ }^{178}$ Message from LTC Peter Rodd (SCAO) to AMGOT HQ, 5 October, 1943, Eisenhower PrePresidential Papers, ser. 3, box 12, DDEL.
} 
Local CAOs became burdened with continual requests for political assemblies, most frequently to organize opposition against the King. This burden of political oppression was complicated for the ACC/AMG, with the outcome of Moscow Conference in October 1943 that further strengthened the tidal wave for political change. The formal declaration for Italy states:

Foreign Secretaries of the United States, the United Kingdom and the Soviet Union have established that their three governments are in complete agreement that Allied policy toward Italy must be based upon the fundamental principle that Fascism and all its evil influence and configuration shall be completely destroyed and that the Italian people shall be given every opportunity to establish governmental and other institutions based on democratic principles. ${ }^{179}$

However, one caveat to the Moscow conference was the absence of any date that political reform was to take place. Specifically, the Three Power Declaration states "so long as active military operations continue in Italy the time at which it is possible to give full effect to the principles set above will be determined by the Commander in Chief." 180 The strange and transient nightmare for the Italian people was seen as never-ending, and the political dissatisfaction grew among the occupied population. Using the directives from the Moscow Conference as its basis, the opposition movement in Naples grew stronger using the ambiguity established between the zones of AMG. The Moscow Declaration reinforced the strictest of defascization policies, calling for the extirpation of all institutions and organizations created by Fascism, as well as the removal of all Fascist elements from public life. ${ }^{181}$ Garnering support in rear areas, opposition parties organized together, bound on the principle that King Emmanuel sponsored Fascism and at least was partially responsible for the Italian suffering under Mussolini. Opposition parties demanded representation and called for an open Italian cabinet. Conglomerating Communists, Socialists,

${ }^{179}$ The Avalon Project, Joint Four Nation Declaration, October, 1943 (Moscow Conference), Lillian Goldman Law Library, Yale Law School, http://avalon.law.yale.edu/wwii/moscow.asp (accessed 5 February 2014).

\footnotetext{
${ }^{180}$ Ibid.

${ }^{181}$ Holborn, 18.
} 
Christian Democrats, Liberals and Action and Labor Democrats opposition parties, a united organization emerged Il Comitato di Liberazione Nazionale or Committee of National Liberation. ${ }^{182}$ The formation and activities of Committee of National Liberation in Naples directly affected ACC/AMG operations, due to the military significance within the city. Naples served as a logistics hub because of its substantial port capacity that directly funneled supplies and personnel to the frontline on approach to Rome. CAOs continually dealt with growing dissent of political actors, while waiting for political advisor guidance. The ability for AMG personnel to remain politically neutral, yet enforce laws of governance, became increasingly difficult and less supported by the Italian populace. For instance, on December 20, 1943, the Committee of National Liberation hosted a political rally at the University of Naples, without CAO approval. When an AMG officer attempted to disperse the meeting, students threw stones and the carabinieri fired shots in the air to scare off the crowd. ${ }^{183}$ It became impossible for CAOs to remain politically neutral and simultaneously enforce the limitation of the growing political movement.

Ultimately, due to political revolution from agents like the Committee of National Liberation, calls for economic reforms, and a general perception to alleviate direct control, the Allied Commission adopted a more liberal policy towards the Italian people. Mr. Harold Macmillan, British Resident Minister at AFHQ, and future acting president of the Allied Commission, summed up the general political attitudes to the treatment of Italy as political entity: In addition, this more lenient mood seems to me greatly in the interests of the world in general. Whatever may be the postwar policy toward Germany, we have accepted Italy into a position different from that of a beaten enemy; we have invented and, to some

\footnotetext{
${ }^{182}$ Harris, 134.

${ }^{183}$ Coles and Weinberg, 438.
} 
extent, benefited by the doctrine of co-belligerency; and from the larger aspect, prosperity like peace is indivisible. ${ }^{184}$

Based on its inability to halt the demand for political reform, AFHQ reinterpreted the directives established for Sicily in late 1943. The clarified directives gave "the Military Governor discretion to permit the Italian people to participate in political activities, which did not lead to rioting and disorder, including among these the right of peaceful assembly, attendance at meetings of political committees, and the publication and distribution of political writings," even those criticizing the Italian monarchy. ${ }^{185}$ This reversal, made out of necessity, greatly complicated the strategic mission of ACC/AMG in regards to the establishment of a stable Italian Government in which it could transfer territory and reduce Allied requirements.

Political advisors and ACC/AMG liaisons to the Badoglio Government feared that political upheaval would reverse the progress made by the Italian Administration and possibly further delay the transfer of territory to King's Italy. In a message from the Supreme Allied Commander, Mediterranean Theater to the CCS on February 18, 1944, GEN Wilson highlighted the rapidly changing political events. The "political situation is developing faster than had been foreseen, and has outrun previous telegrams from Algiers [Location of AFHQ]. There are already indications that opposition tactics may threaten to dislocate administration." ${ }^{\text {"186 }} \mathrm{He}$ described the Committee of National Liberation activities from Naples and the precarious position in which it placed the Allied Control Commission in its requirement to enforce governance. GEN Wilson stated,

They [Committee of National Liberation] have been operating from AMGOT Italy [Naples] and any action against them for subversive activity against the Badoglio Government can only be taken by us [Allied Forces]. We cannot possibly allow this sort

\footnotetext{
${ }^{184}$ Komer, ch. 9, 33.

${ }^{185}$ Harris, 136.

${ }^{186}$ Coles and Weinberg, 438.
} 
of thing to go on. The present attitude of the opposition threatens to interfere with our Military Operations more seriously than any like repercussions to an abdication and a change in the Government. ${ }^{187}$

The political environment soured so quickly, that Allies' political support to King Emmanuel and the Badoglio Government threated CAO efforts in other areas and the general intention of a viable co-belligerent.

Initially, Prime Minister Churchill was opposed to a governmental shakeup to ease the political opposition, but reversed his thought in late February 1944 saying, "I am convinced that a clear decision cannot be delayed and cannot be made dependent on the progress of the battle of Rome." 188 President Roosevelt echoed this sentiment in his response, "My feeling is that we should assure at the earliest opportunity the active co-operation of the liberal political groups by bringing them into the Italian government." ${ }^{189}$ Politically, the Allies painted themselves in a corner with the adoption of the strictest anti-Fascist policies. Now that policy had led to the creation of an anti-Fascist opposition group that threatened the interim government, in which the Allies had formed their strategy around. The Allied Control Commission, committed to maintaining a viable Italian Administration, avoid directly suppress the anti-Fascist movement. In a communiqué from President Roosevelt to Prime Minister Churchill, he states, "Our advice from Italy indicates that political situation there is rapidly deteriorating to our disadvantage and that an immediate decision in breaking the impasse between the present government and the six opposition parties is essential. ${ }^{" 190}$ Following the Committee of National Liberation convention in Bari, within Kings Italy, the Badoglio Government and the opposition parties came to a base

\footnotetext{
${ }^{187}$ Coles and Weinberg, 442.

${ }^{188}$ Ibid., 444.

${ }^{189}$ Ibid.

${ }^{190}$ Ibid., 442.
} 
compromise. Essentially, the Committee of National Liberation formed a six party junta within the Badoglio cabinet, and agreed to the eventual replacement of King Emmanuel with an heir successor. A direct message from AFHQ to LTG Taylor expresses the importance of the given point stating "the present arrangement will in no way impair untrammelled right of the people of Italy to choose their own form of democratic government when peace is restored." 191 The political rhetoric of the Moscow Conference forced the Allied Commission to push Marshal Badoglio for a greater representative administration, regardless of the potential effects on military governance. Additionally the Moscow Conference was the first attempt to create tripartite machinery in the field of military governance, specifically including Soviet representation in what had previously been an Anglo-American theater. ${ }^{192}$ The establishment of the Advisory Council for Italy formed a political apparatus to deal with the "day to day questions other than military operations" and to make "recommendations designed to coordinate Allied policy with regard to Italy." 193 The Advisory Council placed additional political advisors from the three Allied nations to counsel the Supreme Commander during the transition of military governance. Future operations in Romania, Bulgaria, Hungary and Japan also adopted the Advisory Council in conjunction with military governance. ${ }^{194}$ While affecting the execution of AMG in Italy, the new framework retained the priority and supremacy of military authority in governance.

Exponentially, the King was falling out of favor among the widespread anti-Fascist movement, following his years of support to Mussolini. The Advisory Council recognized this deterioration. From the Allies' standpoint, the environment formed a divide between support to a

${ }^{191}$ Messge for LTG Taylor, for AFHQ Advance CP from GEN Eisenhower, ref. no. 6248, 12 October, 1943, Eisenhower Pre-Presidential Papers, ser. 3, box 12, DDEL.

\footnotetext{
${ }^{192}$ Holborn, 19.

${ }^{193}$ Ibid.

${ }^{194}$ Ibid.
} 
fellow European monarchy and the military necessity for the Italian Government to become inclusive. The Italian situation also bled over to the domestic politics of the United States, indirectly affecting President Roosevelt's perception of the situation. By the spring of 1944, President Roosevelt was up for re-election and voters of Italian descent viewed his support for the King unfavorably. Recalling Mr. Murphy to Washington, President Roosevelt directed him to negotiate the abdication of the King, but to do so in such a way to avoid alienation of the British perspective. Mr. Murphy recalled, "He [President Roosevelt] left it up to me to figure out how this could be accomplished, if possible without angering Churchill." 195 The call for political reform within Italy spread to America, leaving the two Allied nations divided in their support for the Italian monarchy.

\section{NORTHERN TERRITORY, NEW PROBLEMS}

As Allied Forces continued north along the peninsula, the execution of AMG assumed a predictable pattern especially within the militarized occupied zone behind the frontlines.

Illustrated in COL Goodman's account as CAO outside of Foggia, the local CAO continued their support with providing military governance to the Italian people as best they could. As tactical commanders focused on the fight in the north, CAOs in the immediate zone found themselves with an unexpected level of independence: "In the following days I was given a sector of the divisional front extending to the rear as far as the divisional rear boundary. In this area, at least to the local population, I was the governor. All power rested in my hands. I reigned supreme."196

Locally, the CAOs continued to reestablish normalcy for the Italian people, declaring the AMG proclamations, linking in with the local administration, and most likely facilitating with relief efforts in the form of food and medicine. They continued removing successfully identified

\footnotetext{
${ }^{195}$ Murphy, 202.

${ }^{196}$ Goldman, 53.
} 
Fascists, and establishing criminal courts as required. The particulars fluctuated based on the need and location, but the core of experienced and empowered CAOs met the majority of expectations. COL Goodman recalled, "It was not pleasant but on the whole it was not too bad. Destruction was rife and the norm. Liberated towns were jubilant with the arrival of the Allied Forces. But it was war. Whenever we entered a new community we were quick to exercise our authority.”197

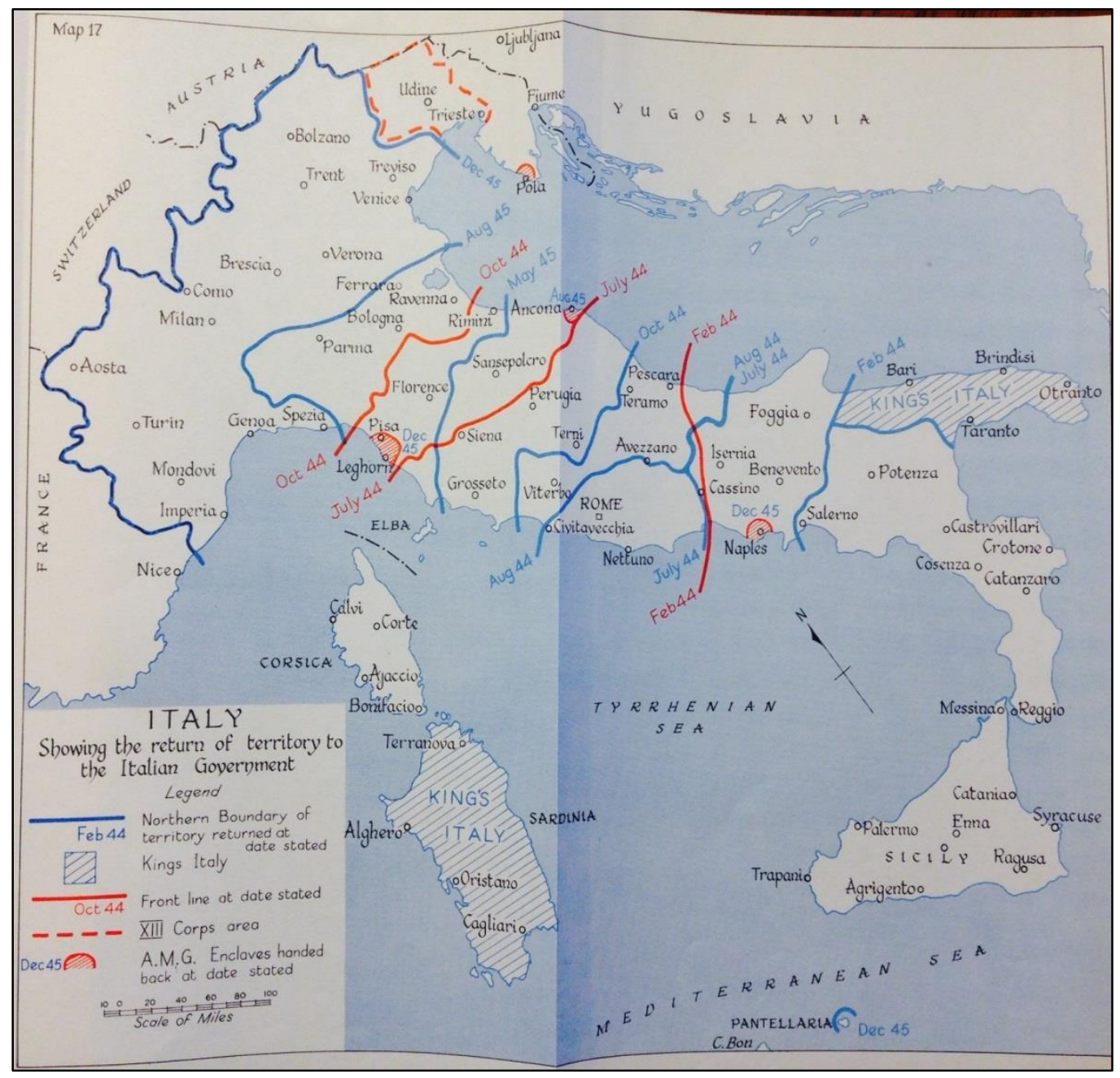

Figure 4. Timeline for Transition of Territory to the Italian Government

Source: Charles R.S. Harris, History of the Second World War, United Kingdom Military Series: Allied Military Administration of Italy (London: Her Majesty's Stationery Office, 1957), 366.

${ }^{197}$ Goldman, 60. 
As the occupation of Italy grew, the CCS called for further civilianization of all possible activities within the Allied Commission in other than AMG operations. Still, AMG operations were to minimize civilian impact on military operations and were mostly confined to those along the frontlines. However, by late 1944, the focus of Fifth and Eighth Armies stretched beyond Florence, leaving much of Italy whole primed for more civilian-led expertise. Additionally, the larger needs of the Italian Government revolved around political and economic issues, making many local CAO missions no longer applicable. In order to meet the CCS guidance, the Foreign Economic Administration and Auxiliary Foreign Service of the State Department offered jobs to CAOs within the Allied Commission. The officers who accepted, were de-commissioned by the War Department and became the new civilian employees in accordance with the civilianization guidance. ${ }^{198}$ This transfer from uniform to suit worked well for the United States side, but the British adapted slowly due to their continued man-shortages back in the United Kingdom. Large portions of experienced AMG personnel moved from Italy to other theaters including France, Austria and eventually Germany.

The hard-won lessons in Italy provided the cobblestone for a more concrete response in the following theaters in the shift to civilian control. The point of contention for the Allied Commission in Italy solidified on the fact that the transition from military administration would not be transferred to civilian authority. As originally designed leading up to the invasion of North Africa, civilian authority and experts eventually replaced military authority. In the case of Italy, the speed of political change and the enactment of co-belligerency removed the requirement for an interim civilian-controlled system. The military administration would not be superseded by an Allied civilian administration, but by the rebuilding of an indigenous Italian government. ${ }^{199}$ In the

\footnotetext{
${ }^{198}$ US Army, Review of Allied Military Government and of the Allied Commission in Italy, 123.

${ }^{199}$ Holborn, 14.
} 
occupation of Germany and Japan, the transition of military authority to civilian authority was conducted and deliberately planned. Albeit a slow and tumultuous process, the re-forging of the Italian administration ultimately solidified the basis for the Allied concept of occupation and governance. While never really applied similarly to the other theaters, the uniqueness of the Italian situation fashioned an organization of military experts that proved they were a mission essential asset for Army commanders.

By mid-1944, the vigorous left-wing movement within the northern territories brought a new challenge to the Allied Commission and Italian government. The Italian patriots, inspired by the feats of the Red Army, and mostly directed by the indigenous Communist Party, provided an armed Italian resistance in the north. ${ }^{200}$ Fighting against the last German forces and the proFascist elements under Mussolini, the patriots essentially formed their own military governance in areas not yet reached by the Allies. Taking bold actions, the Committee of National Liberation, and their armed resistance, impeded German's ability to conduct its scorched earth policy. In Milan, Genoa, Venice, and Turin, patriots liberated those cities, saving industrial and economic centers from ruin and preserving order on their own. ${ }^{201}$ The Committee of National Liberation hunted and executed Fascist elements in the north to include Benito Mussolini, the former duce. Following the second liberation of Italy, the Allied Commission found itself in an incredible new situation, fraught with the potential of instability and revolution. The liberated territory was vehemently anti-German, and the requirement for military governance was essentially staved by the actions of the Left-wing movement. The churning waters of revolution circulated among the Italian people, empowered by the strong favor of the Socialist and Communist movements in the

\footnotetext{
${ }^{200}$ Ellwood, 236.

${ }^{201}$ US Army, Review of Allied Military Government and of the Allied Commission in Italy, 125.
} 
north. ${ }^{202}$ The threat of a potential insurrection resonated with the Allied Commission, as resistance elements of the Committee of National Liberation in Milan bore tension with the Italian Government in Rome. Eventually, the danger of civil war passed, with the inclusion of the northern parties within the Rome cabinet. The new government under Signor Parri, with a much stronger Socialist/Communist representation, encompassed the six opposition parties, while still subject to the rights of the Armistice and Instrument of Surrender.

From an Anglo-American perspective, AMG in Italy became more involved in political competition with the Soviets than providing for the Italian people. The rapid spread of communism in the absence of Fascism, worried the United States and United Kingdom, but no party knew how to halt it. The introduction of Soviet diplomacy into the Italian government exacerbated the situation, as each member of the Big Three attempted to shape Italy into a form favorable to its interests. The United States hoped to impose an image of democracy, much like its own, upon Italy, while the British, especially Churchill, wanted Italy to revert to a British-type monarchy, retaining the royal House of Savoy. ${ }^{203}$ The Soviet Union, observing the growing communist movement as the catalyst for anti-Fascism, saw Italy as a promising stronghold for Communism in the Mediterranean.

The root problem that arose for the Allied Commission and AMG Forces was the inconspicuous nature of the liberated Italian territory. Previously, direct combat operations of Allied ground forces yielded the gain of all territory. In Northern Italy, partisan forces vacated the threat and removed the military necessity for military governance. Industry and administration systems were largely spared and the northern territories avoided devastation for the most part. As described in an Allied Commission report in May 1945, the Committee of National Liberation

\footnotetext{
${ }^{202}$ Harris, 352.

${ }^{203}$ Murphy, 214.
} 
effectively controlled all matters of civil affairs, and instead of building up local government, CAOs faced how to "tactfully take the reins from an existing organization." 204 From the situation on the ground, a consensus grew regarding the end for military governance in Italy. This sentiment resounded in a message from the Allied Commission to 15th Army Group stating, "Now that hostilities are over the problem in N.W. Italy becomes one of civil administration. It is a problem of great complexity both for the Allied Military Government and for the Italian Government which will follow." ${ }^{205}$ The challenge remained regarding how exactly to deescalate the situation between the armed partisans and reconcile with the moderate and friendly Italian government. In the guidance from ADM Ellery Stone, Chief of the Allied Commission for AMG Officials, the apparent political situation in the north called for a gentle touch from local CAOs. In his message he said, "We should all remember that it is for the Italians to determine their own destiny, and that military government in circumstances prevailing now is necessary only for the protection of Allied troops and installations. A light rein with a firm hand should be the order of the day. Above all, we must remember that it is our duty to administer rather than to intervene in the political future of Italy."206

The AMG mission ended slowly and fitfully, with the eventual transfer of nearly all of the northern Italian territory to the Italian Government on December 31, 1945. In the leading months, the requirements for CAOs gradually eased, as the authority of the Italian government expanded in the partisan circles. Essentially, the prime reason for AMG to remain in the north

\footnotetext{
${ }^{204}$ Coles and Weinberg, 551.

${ }^{205}$ Ibid., 584.

${ }^{206}$ Ibid., 561.
} 
was to ensure the stability of the situation, through military presence, until Italy was able to do so on its own. ${ }^{207}$

\section{CONCLUSIONS}

Eisenhower reiterated the importance of Civil Affairs and Military Governance to the

Allied war effort in the weeks leading to the Normandy invasion in the following statement:

Although humanitarian in its results, your job is to help win the war. You have got to get the rear areas organized-electric lights, roads, and supply-and you must keep them working and get them restored as quickly as possible to some semblance of peace time standards, so that they can support to the utmost the armies that are fighting at the front. $^{208}$

In the midst of a bitter and obstinate military campaign, the Allies were not afforded the opportunity to carry out a replacement in state such as seen in Germany and Japan. The military administration established in Germany and Japan was truly only viable since it was conducted after fighting had ceased. ${ }^{209}$ The decision to grant Italy the status of co-belligerency and the attachment to the King and Badoglio immediately following the surrender, limited the vast sweeping nature of reform seen in the nation building of other Axis powers. This legitimacy provided by the King and Badoglio, both helped and hindered the Allied Commision's ability to provide governance through AMG and eventual liaison with King's Italy. This awkward relationship carried forward with subsequent Italian cabinets as all became subject to the guidelines of the Armistice and surrender. The greatest success of civil affairs and military governance was the Allies' ability to fill in through direct support and administration as required. Politically spurred to continue deep de-fascistization policies, many of the Italian administration had to be purged, leaving CAOs to rebuild on their own.

\footnotetext{
${ }^{207}$ Holborn, 21.

${ }^{208}$ Civil Affairs Association, 4.

${ }^{209}$ Ellwood, 237.
} 
The military administration, in regards to civil affairs for post-Fascist Italy, was split along two lines, those in favor of AMG and those advocating for Allied Commission. Allied forces successfully executed AMG in support of the CinC's military requirements for Italy. Most notably along the lines of a united effort, the organization of AMG was completely integrated with American and British personnel at all levels. Despite the differing political motivations and context injected at the strategic and national level, the officers executed AMG operations in the field smoothly. Individual experience and unit expertise was honed, as the campaign in Italy became the testing ground for graduates of the Civil Affairs Training Schools in Virginia and its sister school in Cambridge. The successful creation of the dedicated School of Military Government in Charlottesville, combined with its associated civilian education in the university system, is a standing testament to producing the crop of trained experts. By the time of the invasion of Sicily, Charlottesville was producing 175 graduates every 12 weeks and integrating 450 students a month at 10 American universities. ${ }^{210}$ This training, coupled with similar British efforts, merged for productive joint training in Algiers, which best prepared CAOs for the uncertainty of field operations. The image of CAOs and the benevolent occupation resounded in America in John Hersey's novel, A Bell for Adano, which depicted the actions of MAJ Joppolo, the protagonist responsible for military governance in the town of Adano. ${ }^{211}$ A key element of Hersey's novel was the concept of the individual CAO, dedicated to mission and willing to improvise. This depiction mirrored civil affairs throughout the campaign, as CAOs exercised individual initiative and innovation to meet the requirements for the newly liberated people and the military necessity for the fighting force. The tasks associated with civil affairs and military governments varied from locale to locale along the spectrum of critical and administrative needs.

\footnotetext{
${ }^{210}$ Ziemke, “Civil Affairs Reaches Thirty,” 133.

${ }^{211}$ Zaalberg, 29.
} 
In A Bell for Adano, there is a scene where MAJ Joppolo first attempts to understand the immensity of the AMGOT mission assigned to him. Hersey wrote,

Major Joppolo sat down and looked at the immense pile of AMGOT instructions for the first day. After reading just a fraction of them, he started tearing up the pile in neat quarters and crumpled them up to throw them in the wastebasket.

He stirred and reached into his briefcase again and took out a small black loose leaf notebook. The pages were filled with notes from AMGOT school lectures: notes on civilian supply, on public safety, on public health, on finance, on agriculture, industry, utilities, transportation and all the businesses of an invading authority. But he passed all these pages by, and turned to the page marked: Notes to Joppolo from Joppolo. And he read; 'Don't make yourself cheap. Always be accessible to the public. Don't play favorites. Speak Italian whenever possible. Don't lose your temper. When plans fall down, improvise ... That was the one he wanted. When plans fall down, improvise. ${ }^{212}$

AMG personnel became critical to shaping the success of ground operations by maintaining order and stability behind the troops. Especially evident in Sicily, AMGOT operations served as prime examples of individual initiative and adaptability of single CAOs in the face of a rapidly changing situation. AMGOT alleviated the impact of combat operations on civilians and provided a sense of security for rear operations and its personnel. Under AMG authority, instances of crimes of anti-Allied intent became practically non-existent, in strong contrast to the conditions under German occupation. ${ }^{213}$

The successful nature in which local CAOs integrated themselves into the Italian communities, greatly reduced the tensions with the populace. The majority of CAOs addressed and rectified immediate concerns and needs of the people, or at least convinced the crowds that they were putting forth their best efforts. Unexpectedly, CAOs became instrumental in two special problems, not truly addressed in the planning stages. This included control of the massive movement of refugees and the reabsorption of the armed partisans. In the first scenario, CAOs provided direct contributions through their establishment, support, and utilization of the Italian

\footnotetext{
${ }^{212}$ John Hersey, A Bell for Adano (New York: Alfred A. Knopf, 1944), 14.

${ }^{213}$ Harris, 368.
} 
carabinieri. As a de facto military police force, the carabinieri eased the burden of Allied Forces in handling the treatment of thousands of displaced Italians and foreign nationals moving through combat zones. Second, as the northern Italian territories were liberated from German occupation by armed partisans, AMG Forces tactfully reintegrated and disarmed the Italian partisans. In a very political situation with internal movement consisting largely of armed socialists and communists, CAOs skillfully maintained order despite the growing concern of insurrection against the Italian government.

The success of the Allied Commission is based on two conditional end states. First, the Armistice Control Commission, then Allied Control Commission, and eventually Allied Commission, established the internal conditions within Italy for military operations and the exploitation of the Italian military and resources against the Germany. ${ }^{214}$ As the political situation rapidly advanced, the second conditional end state required the Allied Commission to re-create the basis of a democratic system of a stable inclusive Italian Government. The political decisions and interactions between the United States, United Kingdom and Russia largely influenced and shaped the development of the Italian Administration. Each individual nation deliberate took action in influencing the character of post-hostilities Italy to better benefit of their own concept of the new Europe. While it is highly debatable if the actions of the Allied Commission eased the turmoil within Italy, the Allied Control Commission was crucial in the initial formation of the Badoglio Government. The Allied Control Commission and Advisory Council integrated themselves deeply in the Italian administration and provided the stabilizing factor of legitimacy on the peninsula. Italy, as a co-belligerent and under the rights of Armistice and Instrument of Surrender, was placed in a politically precarious position. The Allied Control Commission provided the necessary continuity to revive the essence of a democratic Italy, sometimes with

\footnotetext{
${ }^{214}$ Harris, 379.
} 
heavy-handed support and influence. The impact of the political climate of a changing Italy on military operations was greatly minimized by Allied Control Commission despite the slow transfer of authority to an indigenous apparatus. Additionally, the Allied Control Commission continually urged an ever-increasing degree of responsibility to be transferred to Italian authority, and became paramount in the expansion of Italian authority. The re-organization and transfer of the ACC/AMG, regional boundaries, and the liaison directive, all facilitated the shrinking footprint of Allied administration away from front lines. The conglomeration of ACC/AMG tasks under one organization expedited the demobilization of civil affairs on a limited scale. With the three distinct tasks of executing the military terms of armistice (Armistice Control Commission), of administering Military Government in the operational zone (AMG), and of exercising general political control over the Italian Government (Advisory Council), the Allied military administration overcame great challenges in its execution. ${ }^{215}$

The failures of Allied Control Commission resulted from indecisive policy decisions towards Italy and a poorly conceived, unwieldy organization. The policy to address military governance by regions was both a benefit and failure for the Allied Control Commission. It was a benefit in the sense that it focused CAO efforts to only areas of Italy occupied by Allied Forces, providing a short-term horizon. This thinking culminated in the decentralization of ACC into three separate areas of control under the three separate headquarters. The stove piping of civil affairs efforts by areas greatly confused the logistical flow and resulted with the Allied Control Commission losing sight of establishing long-term policies. Second, the unwieldy nature of the Allied Control Commission generated undue challenges in establishing its policies, and elevated to the two competing models for civil affairs discussed later.

\footnotetext{
${ }^{215}$ Harris, 385.
} 
Comparing the situation in Italy to AMG operations in Japan or Germany is difficult due to the drastic changes and experiences of all involved. In Japan, the national central administration was maintained, and the United States applied an indirect approach to military governance, using the existing system in place. Additionally, the military government in Japan was solely an American endeavor, which greatly reduced the policy differences between Allied partners. ${ }^{216}$ The operational design for Japan resembled those in a liberated territory, despite the physical occupation of an enemy territory by American Forces. ${ }^{217}$ GEN Douglas MacArthur maximized the use of existing government institutions in a top-down approach, creating stability and efficiency through the indirect administration of the Japanese system. ${ }^{218}$ With Germany, like Italy, Allied Forces had to emplace a more direct approach of military governance. While not preferred, Italian administration inadequacy and the German collapse after Hitler, forced military government to take the reins through direct control in these two nations. ${ }^{219}$ In addition, the physical separation of the Anglo-American towards the execution of military governance seen in Germany was vastly different from operations in Italy. Beginning with Operation Husky and continuing on the Italian mainland, British and American policy towards military governance emphasized joint operations. The United Kingdom used the growing commitment of United States resources to the Mediterranean, the cross-channel attack, and served their own interests by entwining with their American brothers. As military operations finalized in northern Italy in 1944, Britain's ability to mobilize additional forces peaked and formed a stronger reliance on the

${ }^{216}$ Zaalberg, 36.

${ }^{217}$ Cristen, Oehrig, "Civil Affairs in World War II," 30 January 2009, Center for Strategic and International Studies, http://csisdev.forumone.com/files/media/csis/pubs/090130_world_war_ii_study.pdf (accessed 12 August 2013), 5.

${ }^{218}$ Ibid.

${ }^{219}$ Ibid., 6. 
United States. ${ }^{220}$ This Anglo-American reliance benefited both parties in Italy, as national interests never truly clashed with military necessity. Prime Minister Churchill admitted late in 1943, that “our [U.K.'s] man-power is now fully mobilized for the war effort; on the contrary, it is already dwindling." 221 In the military governance of Germany, this unity broke due to political ambitions and interests of all four parties, including the United States, United Kingdom, Soviet Union, and France. Bathed in a sense of retribution, the policy of military governance to Germany decayed between a level of punishment and leniency. ${ }^{222}$

Specifically from an American perspective, the Joint Chiefs of Staff Directive 1067, Directive to Commander-in-Chief of United States Forces of Occupation Regarding the Military Government in Germany, directly altered the conduct of civil affairs in Germany compared to Italy. For instance, it limited civilian relief, a large aspect of civil affairs in Italy, to a means of preventing disease and unrest, with the [German] population remaining at subsistence level. ${ }^{223}$ Additionally, the Joint Chiefs of Staff 1067 forcefully directed the execution of denazification within every facet of German society, where in Italy, the anti-Fascist movement manifested internally. Assistant Secretary of War John McCloy, a leading architect of the Joint Chiefs of Staff 1067, concluded that the directive was "harsh enough to win Russian support and yet moderate enough to prevent total chaos in Central Europe."224 The punitive nature of an occupying force differed drastically from the benevolent approach of the Allied liberators of Italy.

${ }^{220}$ David Reynolds, From World War to Cold War, Churchill, Roosevelt, and the International History of the 1940s (Oxford: Oxford University Press, 2006), 125.

${ }^{221}$ Ibid.

${ }^{222}$ Zaalberg, 33.

${ }^{223}$ Ibid., 33.

${ }^{224}$ Smith, 136. 
The political environment leading to the occupation of Germany was rife with tension among the Allies, not previously seen in the war effort. Prime Minister Churchill, desperately seeking to limit the Soviet Union's ability to dominate Europe militarily, sought stronger commitment from his Anglo-American partners. Many feared that the Soviet Union's aggressive attitude would increase, threatening post-conflict negotiations and the possibility of world peace. President Roosevelt still believed that he could handle Stalin and expected the Russians to abandon their difficult ways and cooperate with the West if their requests were considered judiciously. ${ }^{225}$ The military occupation of Germany ended with the adoption of a zonal construct among the four partners, each functionally independent as laid out during the Yalta Conference. Within each zone, the nations' forces enacted its military governance on its own terms.

${ }^{225}$ Smith, 127. 


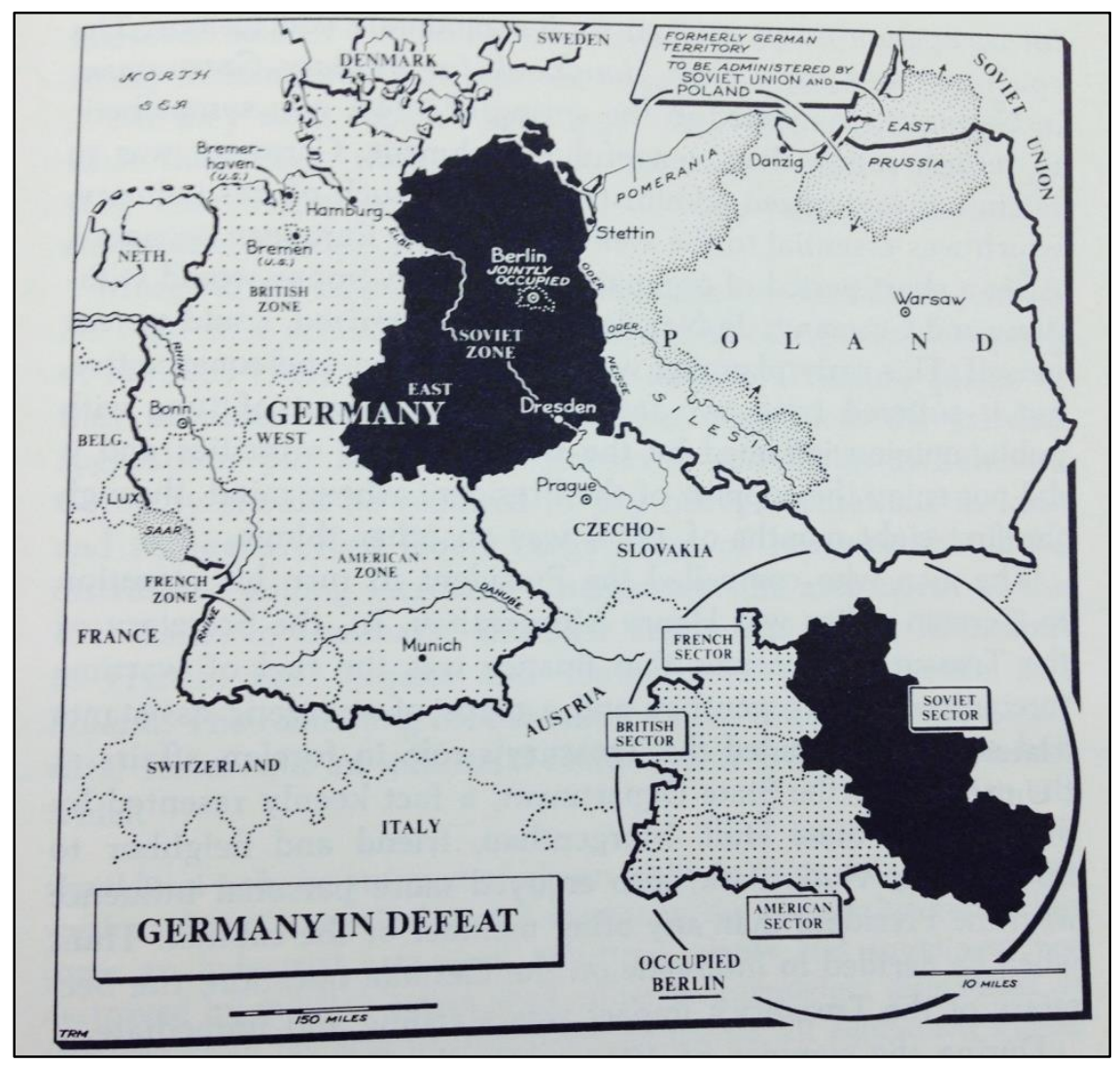

Figure 5. Zones for Military Occupation in Germany

Source: Gaddis Smith, American Diplomacy during the Second World War, 1941-1945 (New York: John Wiley, 1965), 121.

While plagued by policy, indecision, and a convoluted integrated organization, the experience of British and American CAOs paid dividends within their German zones. Similar to the initial operations in Sicily, small mobile CAO teams became the backbone of the AMG.

Upon entering a German town or village in the wake of the Allied advance, these spearhead detachments would first post proclamations and ordinances, telling the Germans what their obligations to the Allied troops were, informing them about curfews and where they had to turn in weapons. A detachment, mostly consisting of two generalist civil administrative officers and two public safety officers, would appoint a new local Germany mayor and select a police chief, often in cooperation with the military police. Temporarily they held absolute power to dismiss or arrest anyone. ${ }^{226}$

${ }^{226}$ Zaalberg, 35. 
Nearly two years of experience in military governance coupled with a general understanding and support from the tactical formations, CAOs within Germany were much better prepared than their counterparts on the eve of the Sicilian invasion.

The emergence of two preferred models of military governance is arguably the most important element of operations in Italy and the lessons learned from the organizational chaos between decentralization and centralized control. ${ }^{227}$ The first model was the separate civil affairs structure, responsible only to the Supreme Commander under a specific organization for military governance. ${ }^{228}$ The example of AMGOT Headquarters in Sicily illustrated this model, which reported directly to the MGS at AFHQ for all elements underneath the Military Governor for Sicily. The second model was the civil affairs detachments, integrated into and responsible to the tactical commander within Seventh, Eighth and later Fifth Armies. This model, while strongly integrated into the fighting force, only had CAO representatives down to the British corps level and American divisional level, limiting its independent capability. ${ }^{229}$

Supporters for a separate civil affairs command argued the benefits to AMG operations, which was isolated from the commander's continually shifting tactical forces and priorities. Supporters, like the British historian Donnison, argued for the success of uniformity of the administrative policy within the separate command, which greatly outweighed the haphazard efforts of divisional units. ${ }^{230}$ Opponents, like the American historian Ziemke, argued that a separate command violated the basis of unity of command. In Ziemke's words, "AMGOT in Italy

\footnotetext{
${ }^{227}$ Zaalberg, 29.

${ }^{228}$ Ibid.

${ }^{229}$ Ibid., 31.

${ }^{230}$ Ibid.
} 
rapidly began to look like a prize example for the fallacy of permitting two independent commands in the same theater."231

While shaped by the rolling landscape of zones within the AMG organization in Italy, the debate between the models carried forward into the occupation of Europe. The rolling aspect seen in the Italian case study, truly favored a mixture of both models. As tactical integration was crucial in the immediate area of the fighting and a separate model was beneficial in rear areas waiting to transition to Italian authority. The underlying fact, that Italy, while occupied and liberated, still endured hostile combat operations, required the adjustment of both models and varying direct and indirect control of the administrative system. These circumstances were never duplicated in other examples of military governance during or since WWII, and add to the uniqueness of civil affairs and military government operations in Italy.

As a whole the civil affairs and military government experience in WWII emphasized the following lessons learned, as highlight by Earl Ziemke's assessment following the final operations in Italy and Germany:

1. Military government appears to be most efficiently conducted when the agency responsible for it is organized along the lines of the political and social institutions of the territory and people involved.

2. Technical channels of communications are to be preferred over those which follow tactical channels of command.

3. It is not sufficient for the military to desire to rid itself of the burden of administration to accomplish this objective ... Thus, as in times past, the Army remained in over-all control of the administration of political, economic, and legal affairs in a defeated country far longer than any of its leaders desired. ${ }^{232}$

These hard-fought lessons learned by the achievements of Allied CAO forces, planning staffs and policy makers throughout the campaign and occupation of post-Fascist Italy have carried forward to today's understanding of civil affairs. Hauntingly echoed in the recent experience in Operation

\footnotetext{
${ }^{231}$ Zaalberg, 31.

${ }^{232}$ Earl Ziemke, The U.S. Army in the Occupation of Germany 1944-1946, (Washington, DC: US Army Center of Military History, 1990), 314.
} 
Iraqi Freedom, the difficulty in establishing effective governance draws heavily on the tactical commander. LTG Ricardo Sanchez's experience in Iraq parallels many of the challenges GEN Eisenhower and GEN Wilson faced in Italy. In Iraq, senior policy makers focused on removal of Saddam Hussein and the Ba'athist administration leaving a shaky Coalition Provisional Authority, under diplomat L. Paul Bremer III, to govern the newly liberated nation. Similar to the fall of Mussolini and the Badoglio government, Saddam was replaced by a fledging governmental system to weak to stand on its own and heavily dependent on the American-led coalition. LTG Sanchez's experience also parallels the political nature of being the lead commander in such an operation. As commander of coalition forces, LTG Sanchez interacted on a daily basis with senior officials in Washington, which he cheekedly compared the sniper fire in Najaf to the cheap shots of Congress. ${ }^{233}$ The political challenges of governing a nation while simultaneously conducting combat operations were faced by both generals. Lastly, the shifting organization of Allied Military Government in Italy may have been much more suited than the well intentioned but misguided Coalition Provisional Authority in Iraq. While stymied by multiple factors, the inability of the Coalition Provisional Authority and the Iraq Administration to stabilize the nation in the first year essentially nurtured the growing insurgency against the United States and it's coalition partners. The stabilization efforts of the Allied Military Government helped mitigate the growth of a viable Italian insurgency. The resemblance of circumstances in civil affairs for Italy and Iraq prove the importance of the Allied effort in military governance as an insightful and relevant historical case study.

${ }^{233}$ Bill Lantham, Review of Wiser in Battle; A Soldiers Story by LTG Ricardo Sanchez, (Leavenworth, KS: Military Review, September-October 2008), 110. 


\section{BIBLIOGRAPHY}

\section{$\underline{\text { Primary Sources }}$}

Army Service Forces. Manual 353-2 Supplement, Civil Affairs Handbook, Italy, Section 2: Supplement, Allied Military Government Manual of Proclamations and Instructions used in Sicily. Washington, DC: Headquarters, Army Service Forces, 27 November, 1943.

The Avalon Project. Armistice with Italy; Instrument of Surrender; September 29, 1943. Lillian Goldman Law Library, Yale Law School. http://avalon.law.yale.edu/wwii/italy 03.asp\#art37 (accessed 23 March 2014).

. Declaration of the United Nations, January 1, 1942. Lillian Goldman Law Library, Yale Law School. http://avalon.law.yale.edu/20th_century/decade03.asp (accessed 23 March 2014).

. “General Orders No. 100: The Lieber Code.” Lillian Goldman Law Library, Yale Law School. http://avalon.law.yale.edu/19th_century/lieber.asp (accessed 23 March 2014).

. Joint Four Nation Declaration, October, 1943 (Moscow Conference). Lillian Goldman Law Library, Yale Law School. http://avalon.law.yale.edu/wwii/moscow.asp (accessed 5 February 2014).

Dwight D. Eisenhower Library Collection of 20th Century Military Records, Series 3. Dwight D. Eisenhower Presidential Library and Museum, Abilene, KS.

Dwight D. Eisenhower Pre-Presidential Papers, 1916-1952. Dwight D. Eisenhower Presidential Library and Museum, Abilene, KS.

Papers of Edward Lilly. Dwight D. Eisenhower Presidential Library and Museum, Abiliene, KS.

Papers of John P. Lucas. Military History Institute, Carlisle, PA.

US Army. Review of Allied Military Government and of the Allied Commission in Italy. Public Relations Branch, Allied Commission, 1945.

US Army, and US Navy. Field Manual 27-5, United States Army and Navy Manual of Military Government and Civil Affairs. Washington, DC: US Government Printing Office, 22 December, 1943.

Walter Bedell Smith Collection of World War II Documents. Dwight D. Eisenhower Presidential Library and Museum, Abiliene, KS.

\section{$\underline{\text { Secondary Sources }}$}

Brooke, Alan. War Diaries: 1939-1945. Berkeley, CA: University of California Press, 2001.

Churchill, Winston S. Closing the Ring. London: Houghton Mifflin, January 1, 1951. 
. Compiled by Charles Eade. Onwards to Victory: War Speeches by the Right Honorable Winston S. Churchill, C.H., M.P. Boston: Little, Brown and Company, 1944.

Civil Affairs Association. Origins of Civil Affairs. http://www.civilaffairsassoc.org/html/ CAA_Article_Origins.pdf (accessed 9 January 2014).

Civil-Military Cooperation Centre of Excellence. CIMIC Messenger 5, no. 1 (March 2013). http://www.cimic-coe.org/download/newsletter/CIMIC-Messenger-2013-01-final.pdf (accessed 9 January 2014).

Coles, Harry, and Weinberg, Albert. Civil Affairs: Soldiers Become Governors. Washington, DC: US Army Center of Military History, 2004.

Daugherty, William, and Andrews, Marshall. A Review of US Historical Experience with Civil Affairs, 1776-1954. Baltimore, MD: Operations Research Office, Johns Hopkins University, 1961.

Davis, Kenneth S. Experience of War, The United States in World War II. Garden City, NY: Doubleday \& Company, 1965.

Dobbins, James, Michele A. Poole, Austin Long, and Benjamin Runkle. After the War: Nation Building from FDR to George W. Bush. Santa Monica, CA: RAND Corporation: 2008.

Donnison, F.S.V. Civil Affairs and Military Government Central Organization and Planning. London: Her Majesty's Stationery Office, 1966.

Ellwood, David. Italy 1943-1945. New York: Homes and Meier Publishers, 1985.

Fisher, Ernest F. United States Army in World War II Special Studies: Cassino to the Alps. Washington, DC: US Army Center of Military History, 2004.

Fisher, Thomas R. "Allied Military Government in Italy." Annals of the American Academy of Political and Social Science 267 (1950): 114-122.

Garland, Albert N., and Howard M. Smyth. The Mediterranean Theater of Operations: Sicily and the Surrender of Italy. Washington, DC: US Army Center of Military History, 2004.

Goodman, Walter F. Jr. Excerpt of An Autobiography and Memoirs of Walter F. Goodman, Jr., A Soldiers Story. Civil Affairs Association. http://www.civilaffairsassoc.org/pdf/col_ goodman_memoirs.pdf (accessed 24 February 2014).

Hamilton, Nigel. Master of the Battlefield; Monty's War Years 1942-1944. London: McgrawHill, 1984.

Harris, Charles R.S. Allied Military Administration of Italy, 1943-1945. London: Her Majesty's Stationery Office, 1957.

Hayward, Edwin J. "Co-Ordination of Military and Civilian Civil Affairs Planning," Annals of the American Academy of Political and Social Science 267 (1950): 19-27.

Hersey, John. A Bell for Adano. New York: Alfred A. Knopf, 1944. 
Hicks, Kathleen H., and Christine E. Wormuth. The Future of U.S. Civil Affairs Forces, A Report of the CSIS International Security Program, February 2009. Center for Strategic and International Studies. http://csis.org/files/publication/130409_Hicks_FutureCivil Affairs_Web.pdf (accessed 20 February 2014).

Holborn, Hajo. American Military Government: Its Organization and Policies. Washington, DC: Infantry Journal Press, 1947.

International Committee of the Red Cross. Regulations concerning the Laws and Customs of War on Land. The Hague, 29 July 1899. http://www.icrc.org/ihl/INTRO/150?OpenDocument (accessed 13 December 2013).

Joint Chiefs of Staff. Joint Chiefs of Staff Directive 1067, Directive to Commander-in-Chief of United States Forces of Occupation Regarding the Military Government in Germany, April 1945. http://germanhistorydocs.ghi-dc.org/sub_document.cfm?document_id=2297 (accessed 20 March 2014).

. Joint Chiefs of Staff Directive 1380, Basic Directive for Post-Surrender Military Government in Japan Proper, November 1945. http://www.ndl.go.jp/constitution/ e/shiryo/01/036/036tx.html (accessed 20 March 2014).

Lantham, Bill. "Review of Wiser in Battle; A Soldiers Story by LTG Ricardo Sanchez." Military Review, (September-October 2008): pgs 34-35.

Komer, Robert. Document No. R-16436.11, Civil Affairs and Military Government in the Mediterranean Theater. Washington, DC: Department of the Army, 1950.

Mason, John B. "Lessons of Wartime Military Government Training" Annals of the American Academy of Political and Social Science 267 (1950): 183-192.

Murphy, Robert D. Diplomat Among Warriors: The Unique World of a Foreign Service Expert. New York: Doubleday and Company, 1964.

Oehrig, Cristen. "Civil Affairs in World War II," 30 January 2009. Center for Strategic and International Studies. http://csisdev.forumone.com/files/media/csis/pubs/090130_world_ war_ii_study.pdf (accessed 12 August 2013).

Office of the Historian. "The Casablanca Conference, 1943." U.S. Department of State. http://history.state.gov/milestones/1937-1945/casablanca (accessed 14 February 2014).

Rennell, Lord. “Allied Military Government in Occupied Territory.” International Affairs (Royal Institute of International Affairs 1944-) 20, no. 3 (July 1944): 307-316. http://www.jstor.org/stable/3018557 (accessed 23 March 2014).

Reynolds, David. From World War to Cold War, Churchill, Roosevelt, and the International History of the 1940s. Oxford, UK: Oxford University Press, 2006.

Sainsbury, Keith. Churchill and Roosevelt at War: The War they Fought and the Peace they Hoped to Make. New York: New York University Press, 1994. 
Smith, Gaddis. American Diplomacy during the Second World War, 1941-1945. New York: John Wiley, 1965.

Stoler, Mark. Allies and Adversaries. Chapel Hill: University of North Carolina Press, 2006.

US Army. Soldier's Guide to Sicily. Burgess and Taylor Family Website. http://burgesses.info/ photo_album/soldiers_guides.html (accessed 23 March 2014).

Zaalberg, Thijs Brocades. Soldiers and Civil Power: Supporting Or Substituting Civil Authorities in Modern Peace Operations. Amsterdam: Amsterdam University Press, 2006.

Ziemke, Earl. Army Historical Series: The U.S. Army in the Occupation of Germany 1944-1946, Washington, DC: US Army Center of Military History, 1990.

. “Civil Affairs Reaches Thirty.” Military Affairs 36, no. 4 (December 1972): 130-133. 